Engineering History and Heritage

Volume 165 Issue EH1

The construction of the Kiev Suspension Bridge 1846-1853

Vignoles
Proceedings of the Institution of Civil Engineers Engineering History and Heritage 165 February 2012 Issue EH Pages 21-45 http://dx.doi.org/10.1680/ehah.2012.165.1.21 Paper 1000012

Received 25/08/2010 Accepted 18/07/2011

Keywords: biography/bridges/history

\title{
The construction of the Kiev Suspension Bridge 1846-1853
}

John Vignoles MA, CEng, MICE

Civil Engineer, retired

In 1846, the Tsar Nicholas I of Russia commissioned Charles Blacker Vignoles to build a fixed crossing over the River Dnieper at Kiev. Opened in 1853, the resultant suspension bridge, involving the construction of foundations in the fast-flowing river, was the largest multispan suspension bridge in Europe at the time. In the paper, the author, a direct descendant of C.B. Vignoles, describes the design, procurement and construction of the bridge between 1846 and 1853 , drawing on information from Vignoles' journals and letters, and also from other contemporary documents. He also makes use of material derived from recently discovered sketches and progress photographs taken by John Cooke Bourne and Roger Fenton - this was one of the first times photography had been used specifically to record construction progress.

\section{Introduction}

\subsection{Design and construction of Kiev Bridge}

The Tsar Nicholas I Chain Bridge across the River Dnieper at Kiev (see Figure 1), was designed and constructed by Charles Blacker Vignoles (1793-1875), the English civil engineer who is more likely to be remembered for his railway work. Opened in 1853, after 7 years of painstaking work, it was the first multispan suspension bridge in Europe.

In the paper, the author, a civil engineer and great-great-grandson of C.B. Vignoles, describes the design and construction process followed, drawing on information from Vignoles' journals and letters, and also from other contemporary documents.

He also makes use of material derived from recently discovered sketches and progress photographs taken by John Cooke Bourne and Roger Fenton - this was one of the first times photography had been used specifically to record construction progress (Chrimes, 1997).

\section{Initial design}

\subsection{Invitation}

Charles Blacker Vignoles was a civil engineer of considerable experience (Cross-Rudkin et al., 2008; Skempton et al., 2002; Vignoles, 1889; Vignoles, 1982). Although his work up to 1846 had been mainly in England and Ireland, he had for some years been considering the possibilities of work in Russia, where the transport system was in its infancy. In 1840 he had acted as guide to General Tcheffkine, the Russian director-general of roads and bridges. More recently, he had been corresponding with the British Consul General in Warsaw, Colonel du Plat of the Royal Engineers, who had an understanding with two Birmingham-born brothers, Alfred and Donald Evans, who had operated an established manufacturing business in Warsaw since 1818, and had investments in Russia.
In December 1846, Vignoles returned from a 2-month break to find advice from Colonel du Plat that Tsar Nicholas I was inviting designs for a bridge crossing the River Dnieper at Kiev, to be submitted in St Petersburg by the end of January 1847. He decided to submit a proposal, a decision that was to change his life forever.

\subsection{The task}

This was not a straightforward project, as a result of the difficult conditions that were dictated by the physical characteristics of the location, conditions that were ultimately to prove even more challenging than Vignoles may himself have suspected.

The River Dnieper at Kiev was slow-moving and sluggish in summer, and frozen in winter. It was a main highway for barge traffic, mainly timber but also other commodities. During the summer, when the river was free-flowing, the $2200 \mathrm{ft}(670 \mathrm{~m})$ wide river could be crossed by a bridge of boats. In contrast, during the winter, the river could only be crossed over the ice. Problematically, there was no permanent crossing available all the year round, as the bridge of boats could not survive the intermediate freeze/thaw period, when the river currents could be extreme.

As Vignoles was later to explain in an article in the London Times, '.. it became a necessary condition that the number of piers of any bridge to be built there should be the fewest possible, with the largest openings between them. Hence it seemed most natural that, within the given limit of expense, the principle of a suspension bridge should be preferred.' (The Times, 1850)

Vignoles was familiar with a number of suspension bridges in England (see Table 1). He knew that important decisions would need to be made, in particular the system of deck suspension, whether with wire ropes or wrought iron link chains, and the make-up and stiffness of the deck, whether in 


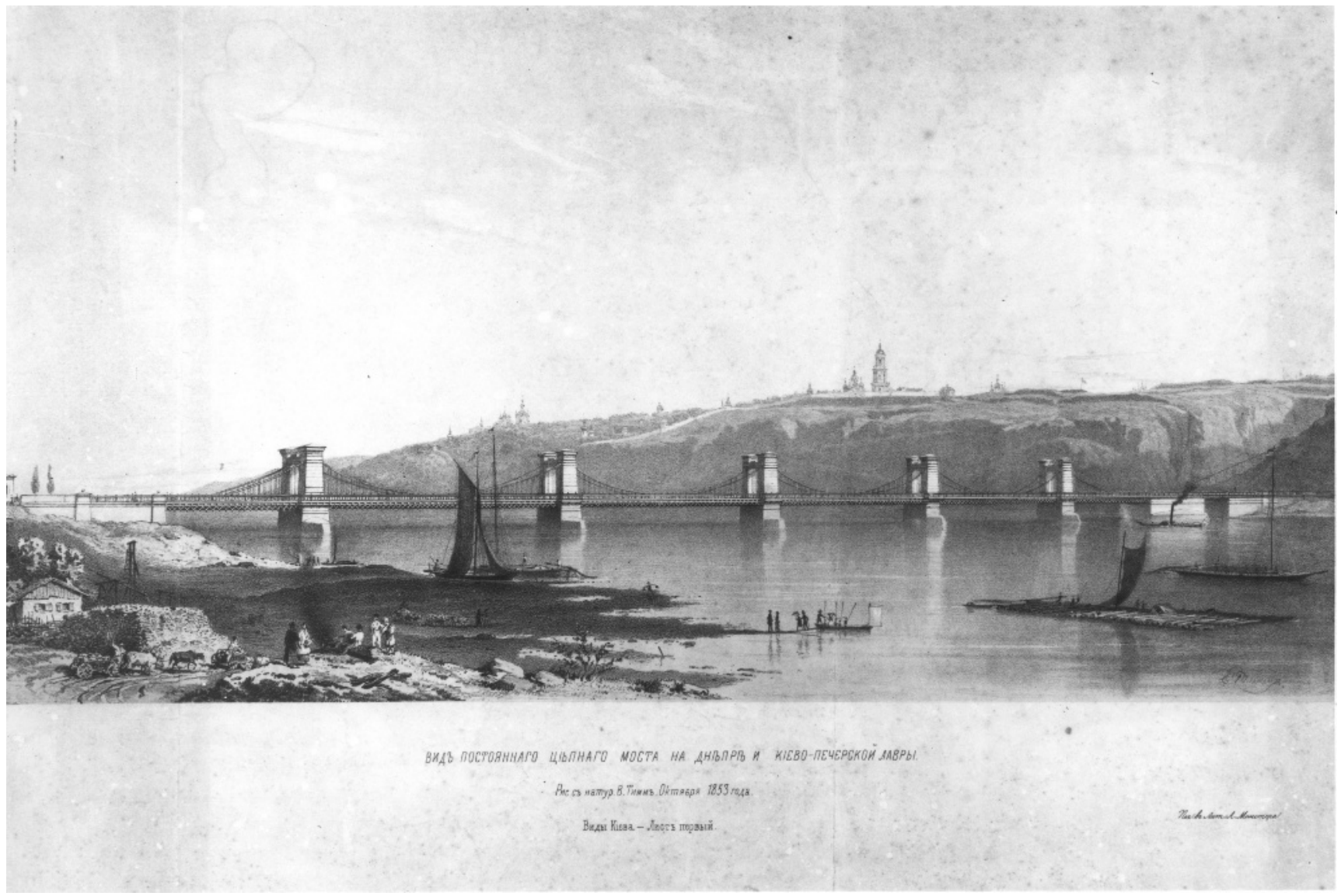

Figure 1. Engraving of Kiev Bridge from upstream - from a water colour by J.C. Bourne, 1853

iron or timber. Failures had occurred on both the Menai and Montrose bridges, requiring significant reconstruction, and reports of these had been reported in the Proceedings of the Institution of Civil Engineers (Maude, 1841; Rendel, 1841).

In the few days available to prepare a preliminary design, Vignoles worked in a number of different directions. He consulted various technical papers at the Institution of Civil Engineers (ICE); and, considering that wrought iron links were preferable to a wire rope suspension system, he wrote to various ironmasters concerning the provision of the links for the suspension chains. He discussed the strengthened Montrose Bridge deck with J.M. Rendel, who had rebuilt it in 1840 . He also consulted with W. Tierney Clark, the designer for the Budapest Bridge, which was presently under construction, with whom he had worked many years before in 1823/4 on the Hammersmith Bridge design (Smith, 1991).

In a space of 2 weeks, Vignoles produced a memorandum of the principles involved and an abstract of quantities to send to his Warsaw partners. He commissioned a proposal document from
Charles Cheffins, an experienced publisher of engineering drawings and documents, whose establishment of expert draughtsmen and lithographers was accustomed to producing proposals at speed for parliamentary submissions (Cross-Rudkin et al., 2008). To accompany the proposal, he commissioned John Cooke Bourne, the illustrator of the London and Birmingham and Great Western Railways, to make a water colour sketch of the crossing.

On the morning of 3 January 1847, we read in Vignoles' journal that he: ' ...received finally the Geometrical and perspective Drawings of the Kiev Bridge magnificently finished and mounted in the manner required and enclosed in a splendid Box.' (Vignoles, 1847).

It remained only to pay $\mathrm{Mr}$ Cheffins for the work and to make arrangements for his office manager $\mathrm{Mr}$ Cummins to conduct business in his absence.

\subsection{The proposal}

Vignoles describes the bridge layout as follows:

'...[The bridge] has four principal openings, each of 440 feet, and two side openings of 225 feet each, and also a passage of 50 feet on 


\begin{tabular}{|c|c|c|c|c|c|}
\hline Bridge & Engineer & Construction date & $\begin{array}{l}\text { Main span length } \\
\text { width }\end{array}$ & $\begin{array}{l}\text { Crossing } \\
\text { length }\end{array}$ & Deck type \\
\hline Menai & Thomas Telford & $1818-1826$ & $\begin{array}{l}580 \mathrm{ft} \times 26 \mathrm{ft} \\
(177 \mathrm{~m} \times 8 \mathrm{~m})\end{array}$ & $\begin{array}{l}1710 \mathrm{ft} \\
(521 \mathrm{~m})\end{array}$ & $\begin{array}{l}\text { Iron cross-beams } \\
\text { Longitudinal timber kerbs }\end{array}$ \\
\hline Hammersmith & Tierney Clark & $1824-1827$ & $\begin{array}{l}410 \mathrm{ft} \\
(125 \mathrm{~m})\end{array}$ & $\begin{array}{l}590 \mathrm{ft} \\
(180 \mathrm{~m})\end{array}$ & \\
\hline Marlow & Tierney Clark & 1829-1832 & $\begin{array}{l}217 \mathrm{ft} \\
(66 \mathrm{~m})\end{array}$ & $\begin{array}{l}437 \mathrm{ft} \\
(133 \mathrm{~m})\end{array}$ & \\
\hline $\begin{array}{l}\text { Norfolk Bridge, } \\
\text { Shoreham }\end{array}$ & Tierney Clark & 1830-1833 & $\begin{array}{l}284 \mathrm{ft} \\
(87 \mathrm{~m})\end{array}$ & & \\
\hline Montrose & $\begin{array}{l}\text { Samuel Brown } \\
\text { J.M. Rendel }\end{array}$ & $\begin{array}{l}\text { 1828-1829 } \\
\text { Recon. } 1840\end{array}$ & $\begin{array}{l}432 \mathrm{ft} \times 26 \mathrm{ft} \\
(132 \mathrm{~m} \times 8 \mathrm{~m})\end{array}$ & $\begin{array}{l}432 \mathrm{ft} \\
(132 \mathrm{~m})\end{array}$ & $\begin{array}{l}\text { Timber cross-beams } \\
\text { Longitudinal timber trusses }\end{array}$ \\
\hline Clifton & $\begin{array}{l}\text { I.K. Brunel } \\
\text { and deck by } \\
\text { others }\end{array}$ & $\begin{array}{l}1836-1843 \\
1860-1864\end{array}$ & $\begin{array}{l}702 \mathrm{ft} \times 30 \mathrm{ft} \\
(214 \mathrm{~m} \times 9 \mathrm{~m}) \\
(\text { final design })\end{array}$ & & \\
\hline $\begin{array}{l}\text { Hungerford } \\
\text { Footbridge }\end{array}$ & I.K. Brunel & $1841-1845$ & $\begin{array}{l}676 \mathrm{ft} \times 14 \mathrm{ft} \\
(206 \mathrm{~m} \times 4.3 \mathrm{~m})\end{array}$ & $\begin{array}{l}1366 \mathrm{ft} \\
(416 \mathrm{~m})\end{array}$ & \\
\hline Budapest & Tierney Clark & 1839-1849 & $\begin{array}{l}666 \mathrm{ft} \times 46 \mathrm{ft} \\
(203 \mathrm{~m} \times 14 \mathrm{~m})\end{array}$ & $\begin{array}{l}1262 \mathrm{ft} \\
(385 \mathrm{~m})\end{array}$ & $\begin{array}{l}\text { Cast-iron cross-beams } \\
\text { Longitudinal iron trusses }\end{array}$ \\
\hline Kiev & Vignoles & $1846-1853$ & $\begin{array}{l}440 \mathrm{ft} \times 53 \mathrm{ft} \\
(134 \mathrm{~m} \times 16 \mathrm{~m})\end{array}$ & $\begin{array}{l}2562 \mathrm{ft} \\
(781 \mathrm{~m})\end{array}$ & \\
\hline
\end{tabular}

Table 1. Comparison list of suspension bridges

the right shore, spanned by a swivel bridge, opening for the passage of the steamboats and other river craft. There are therefore five suspension piers in the river, one mooring abutment on the left bank, another mooring abutment on the Kiev side of the stream (which, on account of the passage for boats beyond it, is actually an island of masonry in the river), and an abutment for the swivel bridge on the right bank. Each of these have required a cofferdam of unusual size, particularly the two last mentioned....'

'...the platform is suspended by chains, all on the same horizontal plane, two on each side of the road; the footpaths project beyond the chains and are carried by cantilevers round the piers exteriorly, so that the foot passengers are completely separated from the horsemen and carriages...' (The Times, 1850)

Figure 2 shows the layout of the proposed suspension bridge, with the Budapest Bridge shown at the same scale. The piers P1 to $\mathrm{P} 5$ are founded in cofferdams D2 to D7. The suspension chains are moored in foundations D2 and D8. The swivel bridge is mounted on abutment D1.

Figure 3 shows the bridge deck arrangement, and Figure 4 the arrangement of the swivel bridge, including foundations.

The philosophy behind the deck or platform construction (see Figure 5) may be found in a technical report from the American Commissioner to the Great Exhibition of 1851, which, from the writing style, was probably written by Vignoles himself.

'...The [four] chains are composed of broad, flat links, twelve feet long, and weighing about four hundred weight each. The tie rods which hang from the chains at each side are two inches in diameter, and are immediately connected to the girders which support the platform.

'The manner in which the platform is constructed is the chief novelty which has been introduced in their structure, and consists in a judicious combination of iron and wood, the object being to obtain a light and stiff platform. Two kinds of girders are adopted here, namely: trussed girders and tension girders; the trussed girders are chiefly composed of wood, and are deeper than the tension girders, which latter are rendered rigid by tension bars. One set of chains supports the trussed girders and the other set supports the tension girders; and these occur alternately. The additional depth of the trussed girders is for the double purpose of stiffening the platform and supporting the foot-paths which are outside of the chains. The trussed girders are connected underneath, at each end, by longitudinal ties which run the whole length, and [by] the balustrades which separate the carriage-way from the footpaths; they act conjointly with the ties underneath in checking any tendencies to undulation, the girders also being braced diagonally to prevent any side play.' (Riddle, 1852) 
Engineering History and Heritage

Volume 165 Issue EH1
The construction of the Kiev

Suspension Bridge 1846-1853

Vignoles
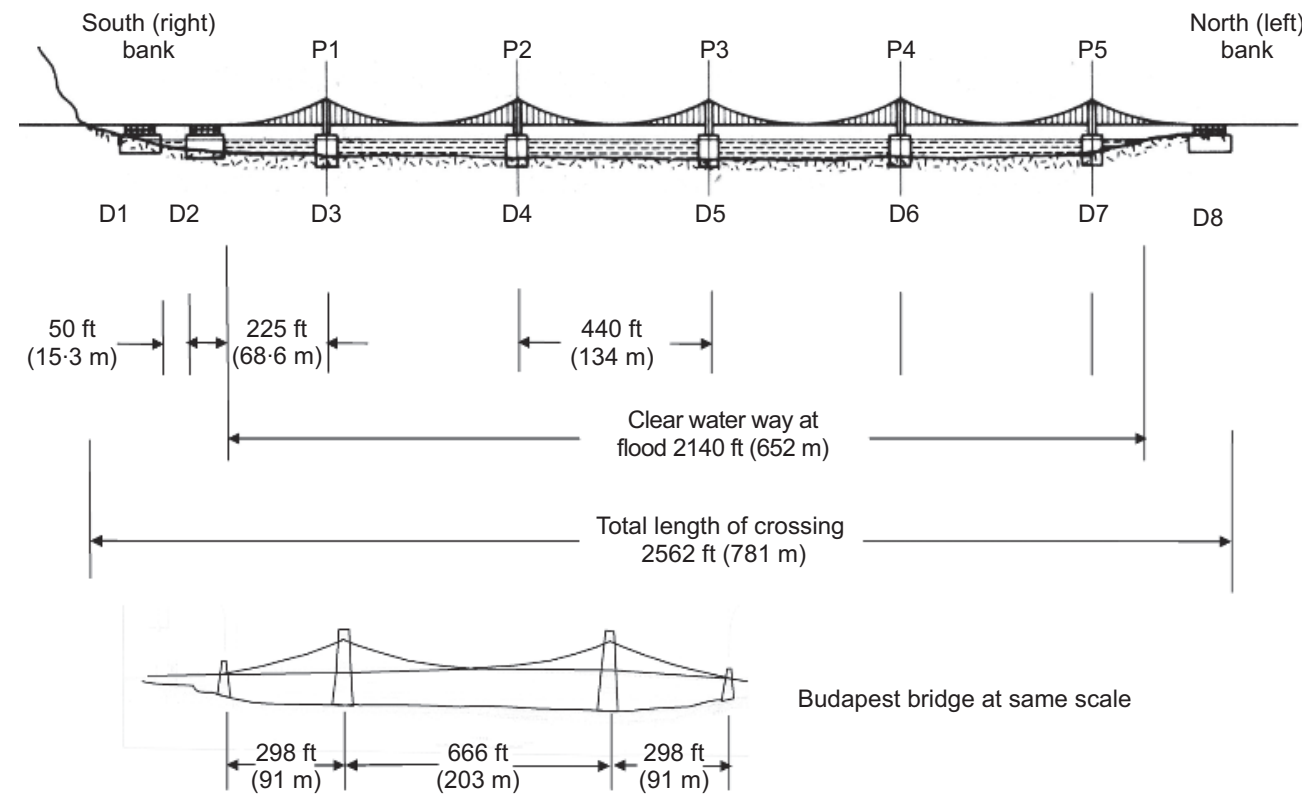

Budapest bridge at same scale

Figure 2. Layout of Kiev Suspension Bridge ( $1 \mathrm{ft}=1 \mathrm{foot}=0 \cdot 3048 \mathrm{~m}$ )

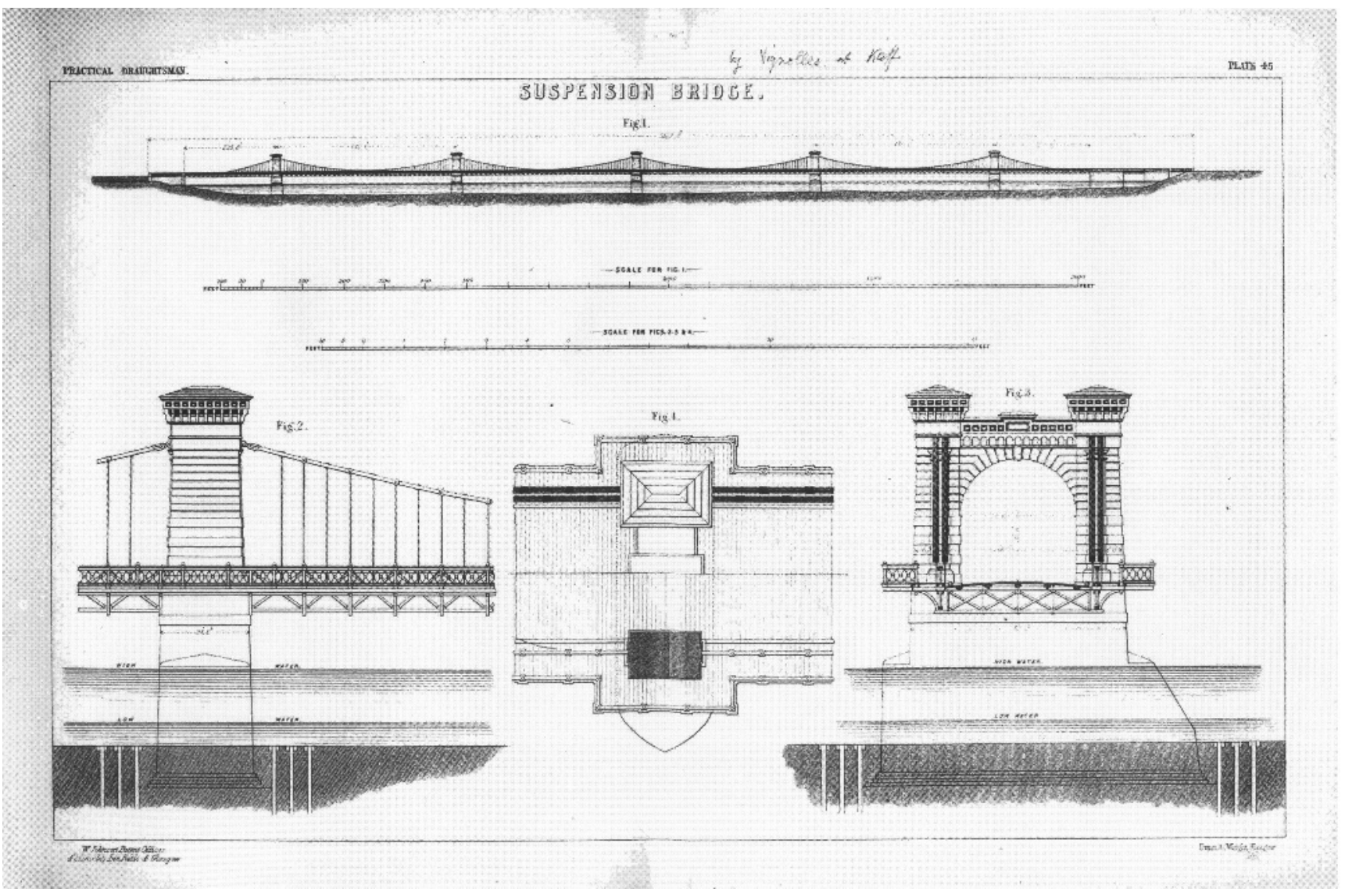

Figure 3. Bridge general arrangement - plate 45 from Practical Draughtsman (Johnson, 1869) ( $1 \mathrm{ft}=1$ foot $=0.3048 \mathrm{~m}$ ) 


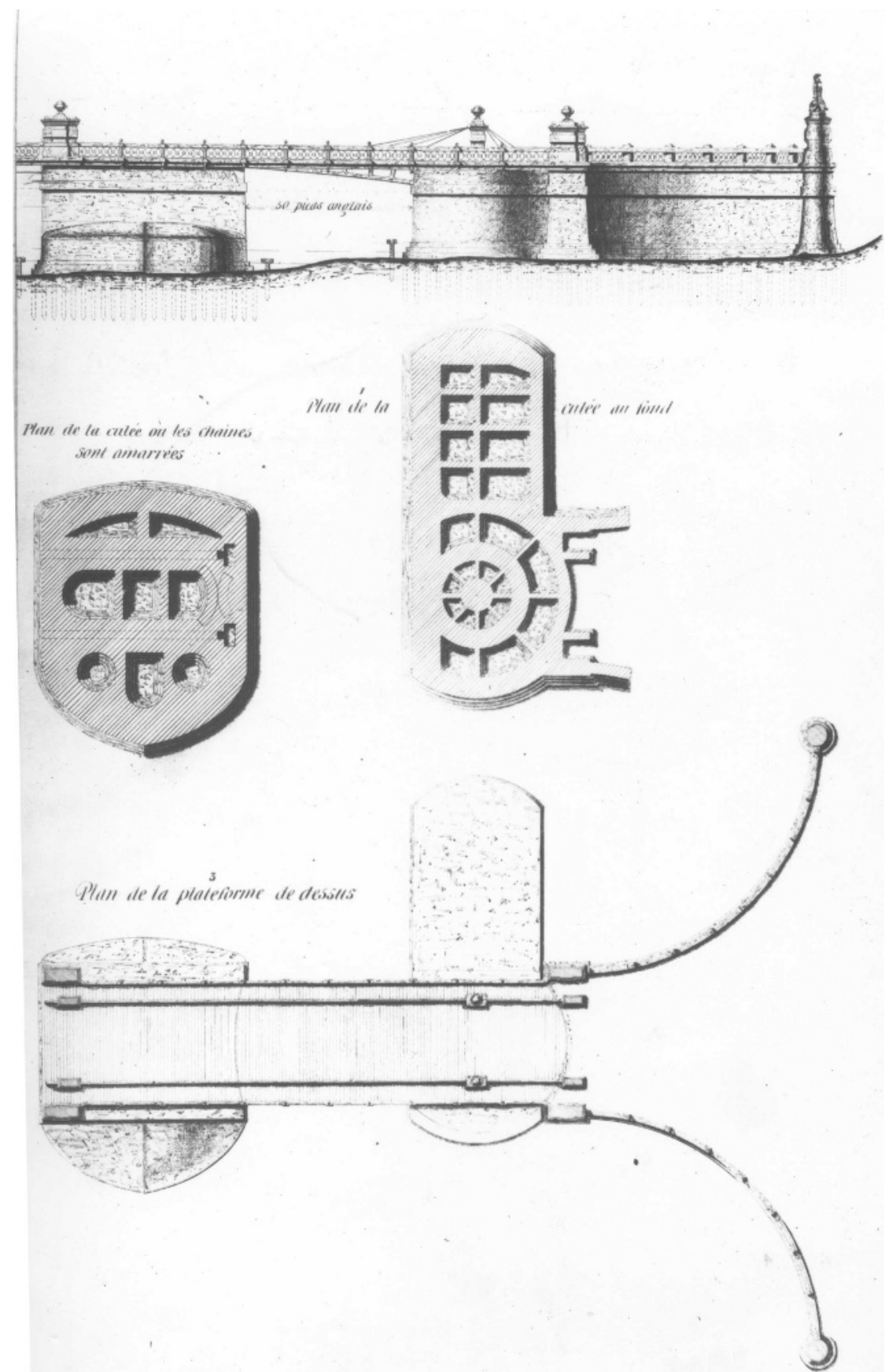

Figure 4. Swivel bridge design drawing - library of St Petersburg State Transport University

The development of the deck design was clearly influenced by the earlier bridges.

The Menai Bridge deck alterations introduced articulated deck bearers, to ensure that the load was shared equally between the four suspension rods (see Figure 6), and the timber kerbs were increased in size to provide some form of longitudinal continuity (Maude, 1841).

For the Montrose reconstruction, Rendel adopted a timber deck, using tensioned cross-beams supported on alternate chains. To provide adequate strength, one cross-beam in six was of a trussed 

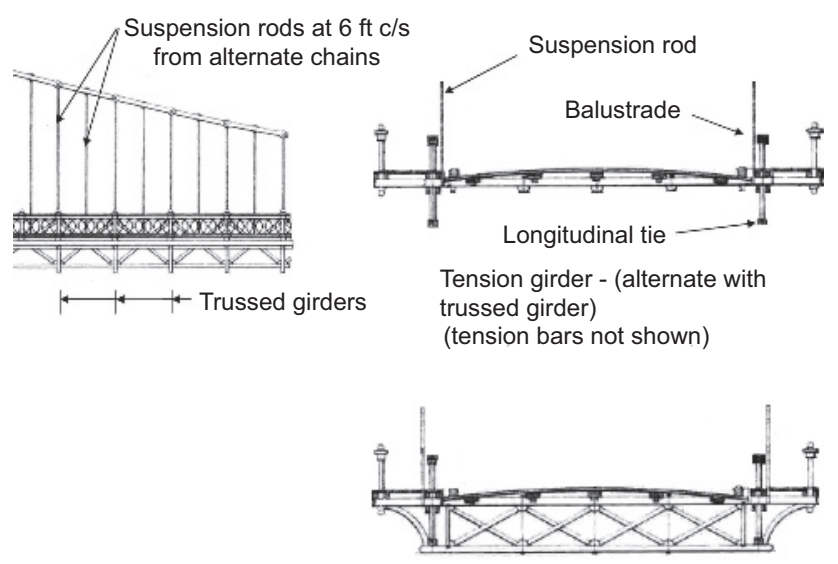

Trussed girder -(at $12 \mathrm{ft}$ centres)

Figure 5. Schematic details of platform girders $(1 \mathrm{ft}=1 \mathrm{foot}=$ $0 \cdot 3048 \mathrm{~m})$ construction, and the structure was further stiffened by longitudinal timber framing (see Figure 7) (Rendel, 1841).

For the Budapest Bridge, Tierney Clark used cast-iron crossbeams, stiffened longitudinally with iron trusses (see Figure 8) (Clark, 1852). There are two pairs of suspension chains, one above the other. The deck cross-beams are hung by twin hangers from alternate chains. A particular innovation at Budapest, which would also be adopted by Vignoles at Kiev, was the use of fully rolled chain links, in which the eyes were part of the same rolling (see section 3.5, below) (Howard, 1849).

\section{Design submission and procurement}

\subsection{Proposal submission: January to March 1847} On 3 January 1847, Vignoles set off for St Petersburg to submit his proposal, accompanied by two of his sons, Hutton aged 24, and Henry aged 20, travelling via Stuttgart, Vienna and Warsaw. In Warsaw, he met Colonel du Plat and the Evans

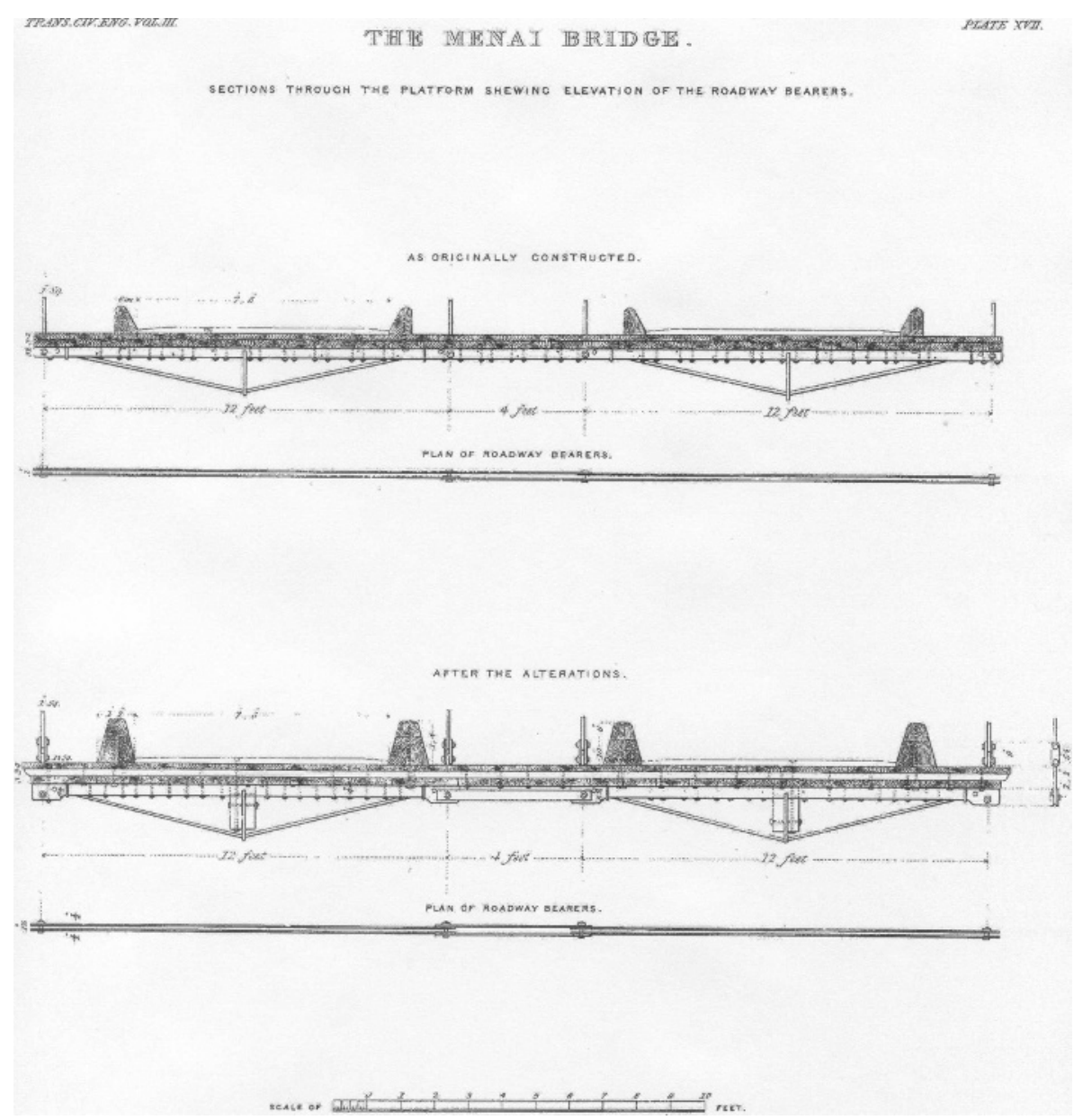

Figure 6. Menai Bridge deck reconstruction (Maude, 1841) $(1 \mathrm{ft}=$ 1 foot $=0 \cdot 3048 \mathrm{~m}$ ) 


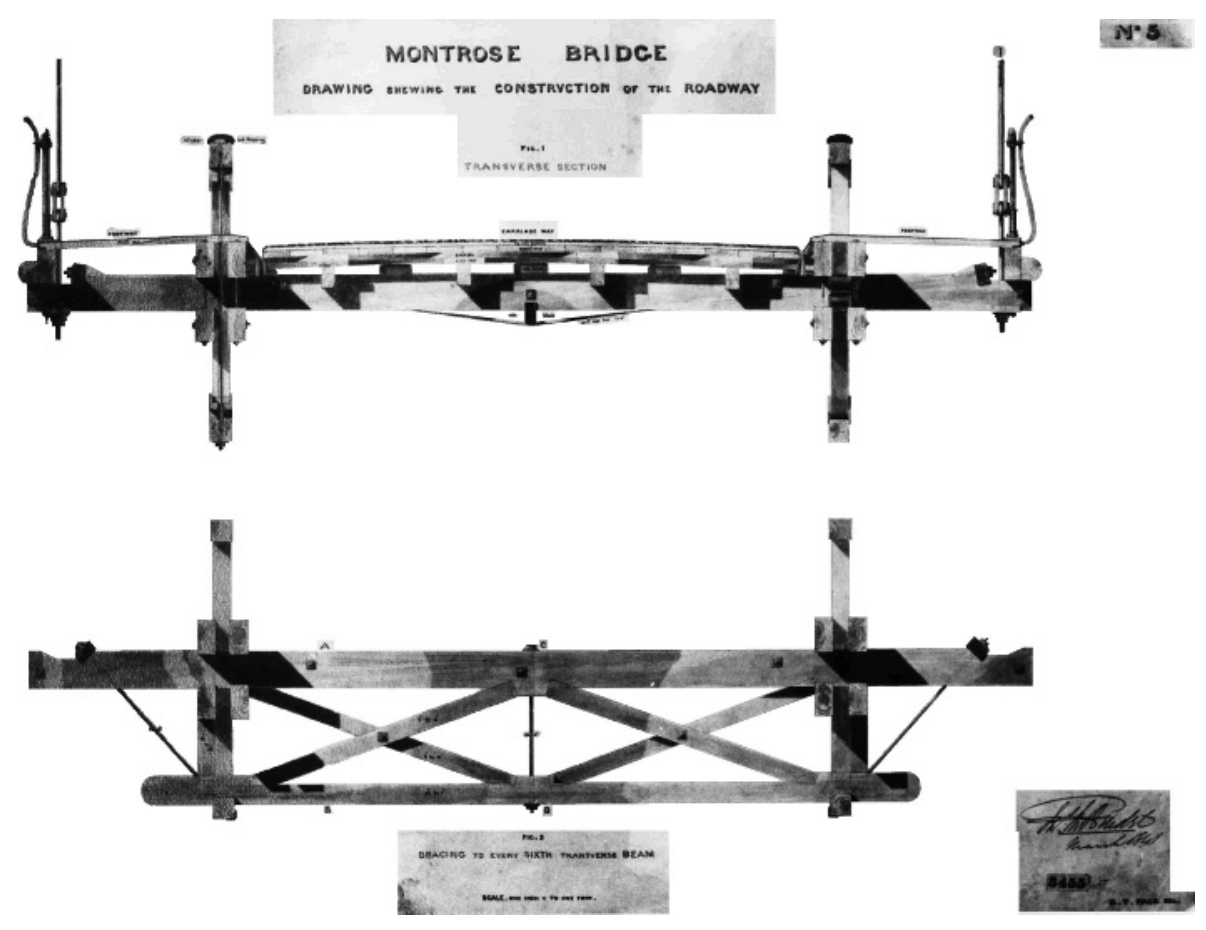

Figure 7. Montrose Bridge deck reconstruction (Rendel, 1841)

brothers, and discussed the form of their partnership. After a pause of several days, while they established the budget and firmed up the wording of the proposal, the journey recommenced, reaching St Petersburg on 1 February.

On 12 February, Vignoles was introduced to Count Kleinmichel, the Minister of Public Works, who asked that he prepare copies of the design for the bridge showing the depth of water at various seasons and also the transverse section of the river. In typical style, while waiting to see the Tsar, Vignoles also sketched outline designs for crossings of three strategic rivers that he had encountered during his journey from Warsaw.

On 16 February, he showed all the plans to the Tsar, who was sufficiently impressed with the proposal for Kiev to ask him to prepare a full design, and promised that a letter would be written to that effect.
With that understanding, by 10 March, Vignoles had returned to London to organise a firm design, stopping in Warsaw to sign an agreement with his partners and with a Polish contractor, Mr Blomberg, who would undertake the construction. He had sent Hutton Vignoles to Moscow and then Kiev on a provisional reconnoitre for materials.

On 7 April 1847, Vignoles received the promised letter giving official acceptance of his proposal for the Kiev crossing at an estimated price of approximately $£ 239000$ (1 670000 roubles), approximately $£ 20$ million in today’s money.

\subsection{Design development: April to June 1847}

Back in London (see Figure 9) Vignoles' next step was to work on the structural design, his personal responsibility, and he approached the task with his usual verve and enthusiasm. He made visits to Montrose, Shoreham and Hammersmith bridges;

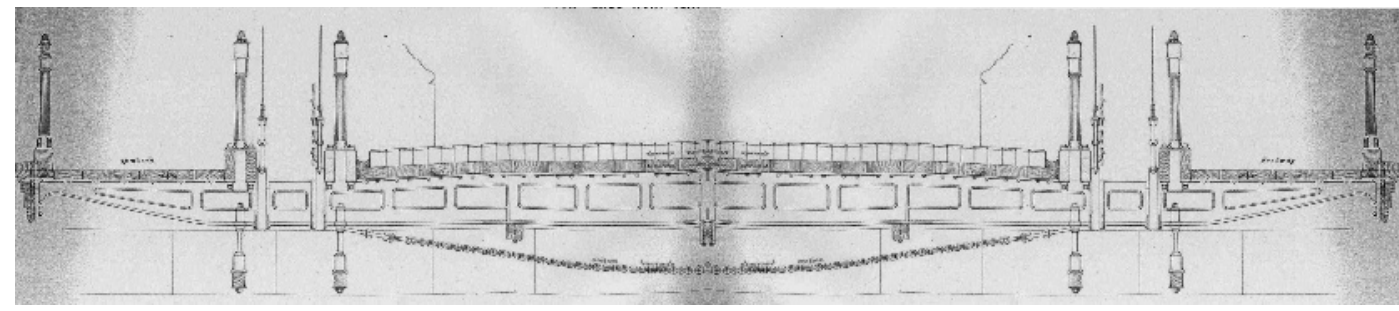

Figure 8. Budapest Bridge cross-section (Clark, 1852) 


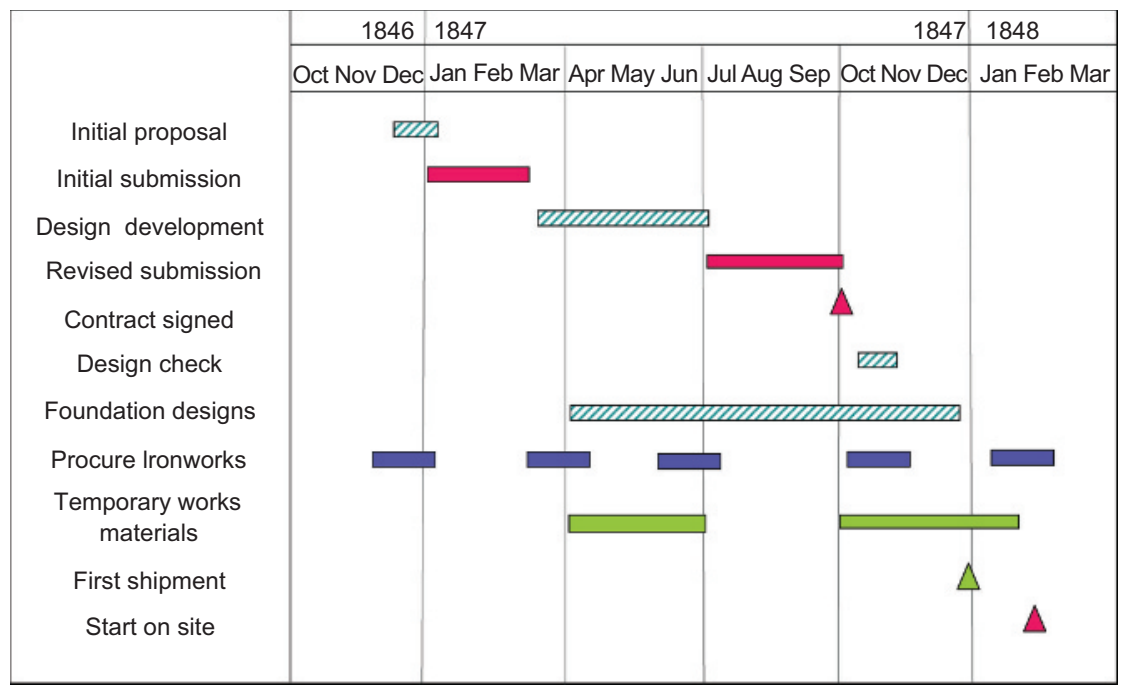

Figure 9. Preconstruction programme

he visited iron works to look at raw material for the chain links; he looked at steam pile driving machines; he investigated the cost of shipping freight to Kiev from Liverpool via the port of Odessa; and he discussed architectural details. Finally, he commissioned John Cooke Bourne to draw a revised proposal.

He also set up a design office at Preston to prepare drawings for the foundation construction, using the services of William Coulthard, who had been associated with Vignoles for a number of years as both engineer and contractor, and was also a close friend of the family. In this work, Coulthard would be assisted by his son, William Robson Coulthard, by Hutton Vignoles, now back from Kiev, and by John England; young engineers who, after working on the bridge construction at Kiev, would all proceed to successful engineering careers (Cross-Rudkin et al., 2008).

On 16 June 1847, the final design proposal was at last complete, and a fresh portfolio prepared for submission to the Tsar. The signed portfolio, entitled 'Dessins Detaillés du Pont Suspendu a Kiév' and signed 'Charles Vignoles, Ingénieur Civil Juillet 1847 No 4 Trafalgar Square London' is today in the Scientific Technical Library of the St Petersburg State Transport University (see Figure 10).

\subsection{The site visit and design approval: July to September 1847}

In July 1847, Vignoles returned to Warsaw with the final design. He then visited Kiev for his first view of the site itself up until now, he had been reliant on descriptions made by others. The journey involved over $80 \mathrm{~h}$ travelling in each direction by coach on unmade roads for a visit of 2 days.
While there, he commissioned searches for timber and stone, and also for a foundry that could make piling shoes.

Back in Warsaw, 8 days later, Vignoles consulted with his partners about the financial agreement. Significantly, as it was to turn out, the risks and rewards rested with Vignoles and Colonel du Plat, who was the senior partner in the venture. The Evans brothers declined to take a share in the risk, but agreed in all other repects to assist him, and to endeavour to get $\mathrm{Mr}$ Blomberg either to continue on the original terms or to take an extra fee for doing the work as the contractor.

Vignoles then returned to St Petersburg, where he was to remain for 6 weeks negotiating the design with the 30-man bridge commission appointed by the Tsar. Various dimensional changes were requested, and the suspension calculations were challenged, with negotiations going round in circles. It soon became clear to Vignoles that no-one was prepared to take responsibility for approving the works. Frustrated by the delays, at the beginning of September Vignoles managed to arrange a meeting with the Tsar, who asked him to confirm personally that his calculations were satisfactory, and to take account of the requested dimensional changes. This he agreed to do.

On 22 September, Vignoles met the Tsar again, this time on site at Kiev, and the various amendments were agreed. Eventually, at the end of September, Vignoles received a signed contract. Vignoles writes in his diary 'Thus after 9 months of tedious discussions this affair of the Kiev Bridge was brought to a satisfactory conclusion.' 
Engineering History and Heritage

Volume 165 Issue EH1
The construction of the Kiev

Suspension Bridge 1846-1853

Vignoles

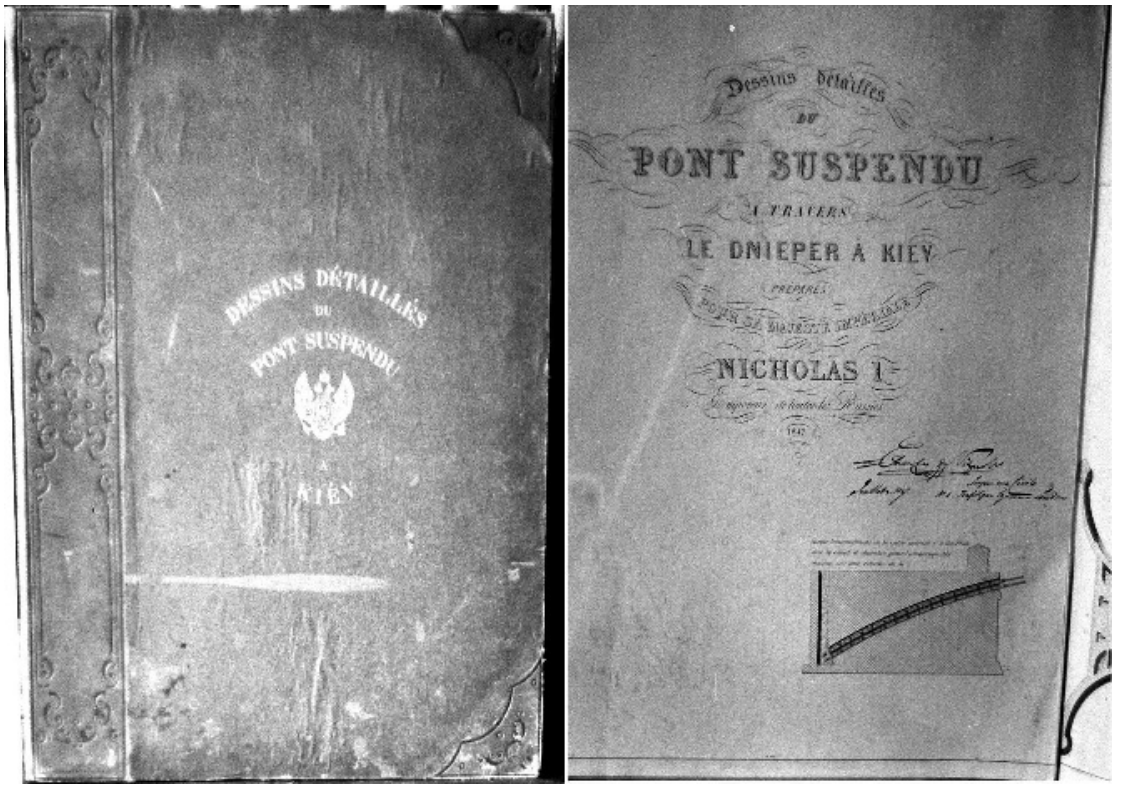

Figure 10. Cover of design portfolio - library of St Petersburg State Transport University

\subsection{Works contract}

Returning to England via Warsaw, Vignoles agreed the terms of the contract with $\mathrm{Mr}$ Blomberg to supply the labour force and construct the works at Kiev, including the procurement of locally available materials of timber and stone. All ironwork and temporary works machinery would be procured by Vignoles in the UK, with payment direct from Russia. The principal quantities involved are listed in Table 2. Before leaving Warsaw for London, Vignoles had a Power of Attorney drawn up to enable Blomberg to order and mobilise the work; he also engaged a Polish engineer to go to Kiev and carry out a preliminary survey of the site.

\subsection{Procurement and mobilisation: October 1847 to February 1848}

On 7 October, Vignoles arrived back in England and immediately started to make preparations for the start of work on site in the new year.

On 16 October, a contract was placed with John Musgrave and Sons, Globe Works, Bolton to supply the temporary works ironwork. The first shipment was loaded at Liverpool and shipped out to Odessa in December, followed by a second shipment in January. In all 22 shipments of permanent and temporary materials would be shipped from England (see Figure 11).

Also in October, Vignoles spent 3 days in Ireland consulting on the mathematics of the design with his friend and colleague, $\mathrm{Mr}$ Thomas F Bergin MRIA, the respected manager of the Dublin and Kingstown Railway, and his nephew Edward Whiteford, who was studying mathematics at Trinity College Dublin. For an independent check, they approached Thomas Romney Robinson FRS, who had been Astronomer Royal at the observatory at Armagh since 1822. As Professor Robinson would accept no fee, Vignoles presented him with a Whitworth slide-lathe. This is a typical example of Vignoles' ability to build a useful and competent network of advisers.

The chain procurement had involved numerous discussions and letters to ironmasters. In 1845, Mr Thomas Howard, of the King and Queen Iron works at Rotherhithe on the Thames, had devised a method of rolling suspension chain links that avoided the need for separately welding the eyes. The works was presently engaged in making 5000 links for the Budapest bridge (Howard, 1849). Vignoles arranged for sample links to be rolled from raw material by Thorneycrofts, a Wolverhampton foundry working under licence from Thomas Howard. Full-size tests were carried out on these links at Fox Henderson's works in Birmingham. The tests demonstrated that the link capacity increases with the pin diameter, leading Vignoles to adopt a pin of 5 in $(12 \mathrm{~cm})$ diameter as opposed to the 4.5 in $(11 \mathrm{~cm})$ pin used at Budapest. Sir Charles Fox later described the tests in a paper to the Royal Society (Fox, 1865). The link drawings were issued on 18 December 1847 to a number of ironmasters, and finally on 23 January 1848 we find Vignoles checking the contract with Fox Henderson for the supply of rods, pins and chains. The quantity of individual links was said to extend approximately 17 miles $(27 \mathrm{~km})$ in length. Each individual link 
MODEL

KIEFF SUSPENSION BRIDGE

Recently erected across the

RIVER DNIEPER

Near the

CITY and FORTRESS of KIEFF

By order of

HIS IMPERIAL MAJESTY NICHOLAS I, EMPEROR

RUSSIA

CHARLES VIGNOLES, FRAS, MRIA, ENGINEER

First stone laid 9 September 1848 - Opened 10 October 1853

The model by Jabez James, A Inst CE, Mechanical Engineer

Scale of model one inch to eight feet - equal to 1/96th (0.0104166) of real length

The suspension chains and bolts executed by Messrs. Fox, Henderson \& Co., London Works, Birmingham

The other iron works executed by Messrs. Musgrove [sic] \& Sons, Globe Works, Bolton-le-Moors

Principal dimensions etc.

Extreme length, 854 yards - nearly half a mile or........

(366 Russian sagenes $=776$ French metres)

Extreme breadth, $171 \frac{1}{2}$ yards or....

(71/2 russian sagenes -16 French metres)

Spans

Each of the four large openings from centre to

centre of the river suspension towers or piers..........

Each of the two side openings, from centre of the

suspension tower to the face of the abutment....

Swivel bridge opening in the clear...

Clear waterway at highest floods...

Height of platform above ordinary summer

water-line.

Greatest rise of floods (after the melting of the snows in

the spring) above the ordinary summer water level....

Greatest depth of water in the channel at summer level....

Ditto at highest floods.

Extreme height from deepest foundations to the top of

caps of the suspension towers or piers,

Breadth of portals piercing the suspension

towers.

Height of ditto

Chord of chains of large openings, clear of

piers.

Versed sine of ditto.
$2562 \mathrm{ft}$ Total weight of all the platforms and rods, clear of the piers (42 lb per

$52 \frac{1}{2} \mathrm{ft} \quad$ square foot)................ 2350 tons

Weight of chains and pins, suspended

clear of the piers......

1076 tons

Total weight of the four chains and

$440 \mathrm{ft}$ pins only

Minimum section area of the four

$225 \mathrm{ft}$ chains, excluding pins and overlaps... $328 \mathrm{sq}$ in

$50 \mathrm{ft} \quad$ Total weight of iron of all kinds

$2140 \mathrm{ft}$ used in the works.

3500 tons

Total quantity of timber used,

$30 \mathrm{ft}$ including temporary works.........

Total quantity of brickwork and

$20 \mathrm{ft}$ masonry and concrete in the

$40 \mathrm{ft} \quad$ works........

$60 \mathrm{ft}$ Proof load per available square foot of suspended platform......

$112 \mathrm{ft}$ Total proof load calculated to be laid on the bridge for testing...

$28 \mathrm{ft}$ Actual load laid on the bridge for

$35 \mathrm{ft}$ the test, $60000 \mathrm{ft}^{3}$ of sand, which being much wetted by heavy rain

$416 \mathrm{ft}$ during the test weighed $1 \mathrm{cwt}$ per cubic

$30 \mathrm{ft}$ foot, being equivalent to the weight of 50000 infantry soldiers or about.
$1500000 \mathrm{cu} \mathrm{ft}$

$500000 \mathrm{cu} \mathrm{ft}$

$63 \mathrm{lb}$

2350 tons

3000 tons

TOTAL ABSOLUTE EXPENDITURE about $£ 432000$ sterling

Table 2. Statistics: transcription of 1854 brochure 


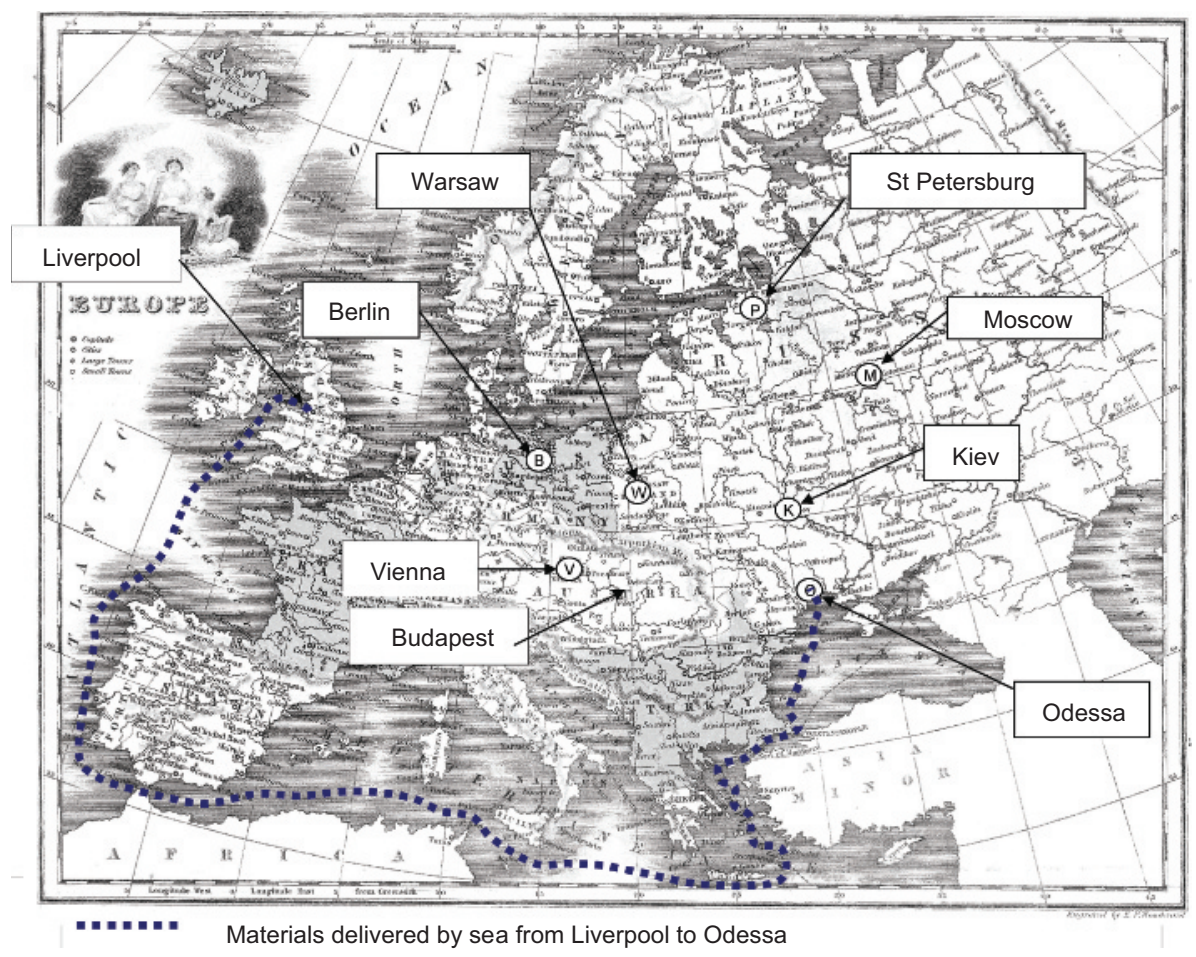

Figure 11. Logistics map

would be tested using a proving machine developed for the purpose.

On 10 December, Vignoles arranged for a first financial drawdown from his bankers and had discussions with Colonel du Plat regarding his share of capital for the finances. Although a form of stage payments had been agreed with the client, responsibility for initial payment rested with the partners as was common at the time, and cash flow would always be a concern. Before leaving London, Vignoles would arrange a Power of Attorney for his office manager, $\mathrm{Mr}$ Cummins, who was based at 4 Trafalgar Square, London, to manage his affairs in his absence.

On 15 December, the foundation drawings were completed. The Preston office was closed and the design assistants travelled to London to join the party for Kiev. William Coulthard (senior) was to remain in England on a salaried basis, to provide a design service to the site as required.

Also in December, Mr Frost, who Vignoles had just appointed as river works engineer, was asked to investigate and procure some piling engines that he had seen working at Perth; and on 16 January 1848, 2 weeks before departure for Kiev, Vignoles travelled up to Newcastle to visit the Nasmyth steam pile drivers at work on the foundations for the Newcastle High Level Bridge. The river cofferdams, which were needed to permit the foundation construction, would require a significant number of timber piles to be driven into the bed of the river.

At the end of January 1848, 4 months after signing the contract, Vignoles set off to Kiev, where he intended to establish his own residence, as he had 10 years previously at Dinting Vale when working on the Woodhead Tunnel on the Manchester to Sheffield Railway. He took with him his daughter, Camilla Croudace (who was estranged from her husband), to keep house for him.

On 19 February 1848, the site team assembled at Kiev. Vignoles was to be chief engineer; with Hutton and Henry Vignoles, John England and William Robson Coulthard as assistant engineers. As well as Mr Frost and his son, there were two mechanical engineers, $\mathrm{Mr}$ Coulishaw and $\mathrm{Mr}$ Bell, and $\mathrm{Mr}$ George Pemberton who was a blacksmith. Mr Dacre White was to be responsible for the shipping import at Odessa. Mr Whiteford, the maths scholar from Trinity College Dublin, joined the team as general assistant. The contractor's agent was Mr Schweitzer, and a Captain Kirchenpauer was construction engineer.

Also in the team was John Cooke Bourne, who had provided the preliminary design illustrations. As resident artist, he would be responsible for producing record drawings and sketches and photographs (calotypes) as required. According to Vignoles' journal, at the close of each season a set of these 
photographs was placed in an album for the client. It is understood that an album for the 1849 and 1850 seasons is in the library of the St Petersburg State Transport University.

A founder member of the photographic society, Vignoles was an early and enthusiastic advocate of the use of photography to record construction, using the latest methods available. In 1852, he would invite Roger Fenton to travel to site to take stereoscopic photographs of the chain erection process. In 1853 , he would buy a new camera from Mr Delamotte, which Bourne would use to great effect. An album of Bourne's photographs for the 1853 season is in the National Museum of the History of the Ukraine in Kiev (Hannavy, 2004).

\subsection{Construction programme}

The construction programme, intended and achieved, is shown in Figure 12, and follows a linear process with working time governed by the seasons of the river. It shows that Vignoles anticipated that the cofferdams would be constructed in the first season (1848), and the foundations would follow in the next (1849). Once the foundations were out of the water, 2 years would be required for the piers and deck construction. This meant that the bridge was expected to be handed over in September 1851, 4 years after signing the contract, before the start of the winter season. As the achieved programme shows, however, there were significant delays to the river works and foundations, which would result in a 2-year delay in bridge completion until September 1853.

\section{Construction 1848}

\subsection{Initial site works}

The layout of the site works is shown in Figure 13. On arrival in Kiev, the team found as expected that it was still winter and the river was frozen over. This enabled them to work relatively dry-shod surveying the line of the bridge, establishing foundation positions, and drilling down to prove the ground. To their satisfaction, they found hard clay on the right bank under the heights. The remainder of the river bed was sand, which would lead to problems with the water-retaining cofferdams at each foundation. Much time was spent preparing plans and sections of the river, and deciding the bridge alignment. Vignoles appears to have carried out much of the direction of the works himself, and his journals are full of detail during this period.

Work also proceeded to establish the construction camp on the north or left bank and to set up and source stone and timber for the works. The course of the supply railway from the heights was also determined. This incorporated an inclined plane, or manually operated cable railway, which was surveyed and constructed by the end of the year, and would be instrumental in conveying materials to the work.

Once the river had thawed sufficiently, piling for both the temporary bridge supports and for the cofferdams started. The temporary bridge was built to carry a railway across the works, with pile bents at $54 \mathrm{ft}(16 \mathrm{~m})$ centres, and sidings at each cofferdam. There were seven cofferdams in number, some in deep water and some in shallow. The basic construction was of two concentric rings of timber piles, with the space between filled with puddle clay. The two rings were tied together with iron straps, and the interior would be propped with a system of timber struts and walings to take the pressure of the water. Figure 14 is a sketch by Bourne showing pile installation proceeding in one of the foundations on the left bank.

Vignoles approached the work on site with his customary optimism. This is evident from a letter he wrote on 16 May 1848 to Robert Stephenson (Cross-Rudkin et al., 2008),

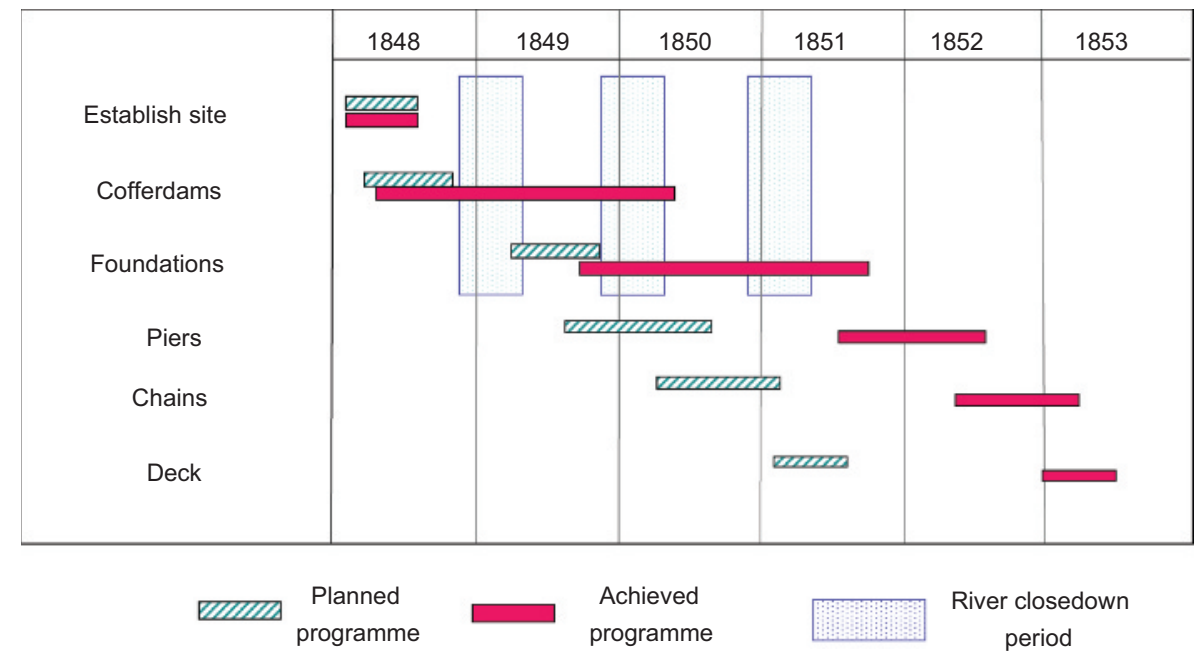

Figure 12. Planned and achieved construction programme 


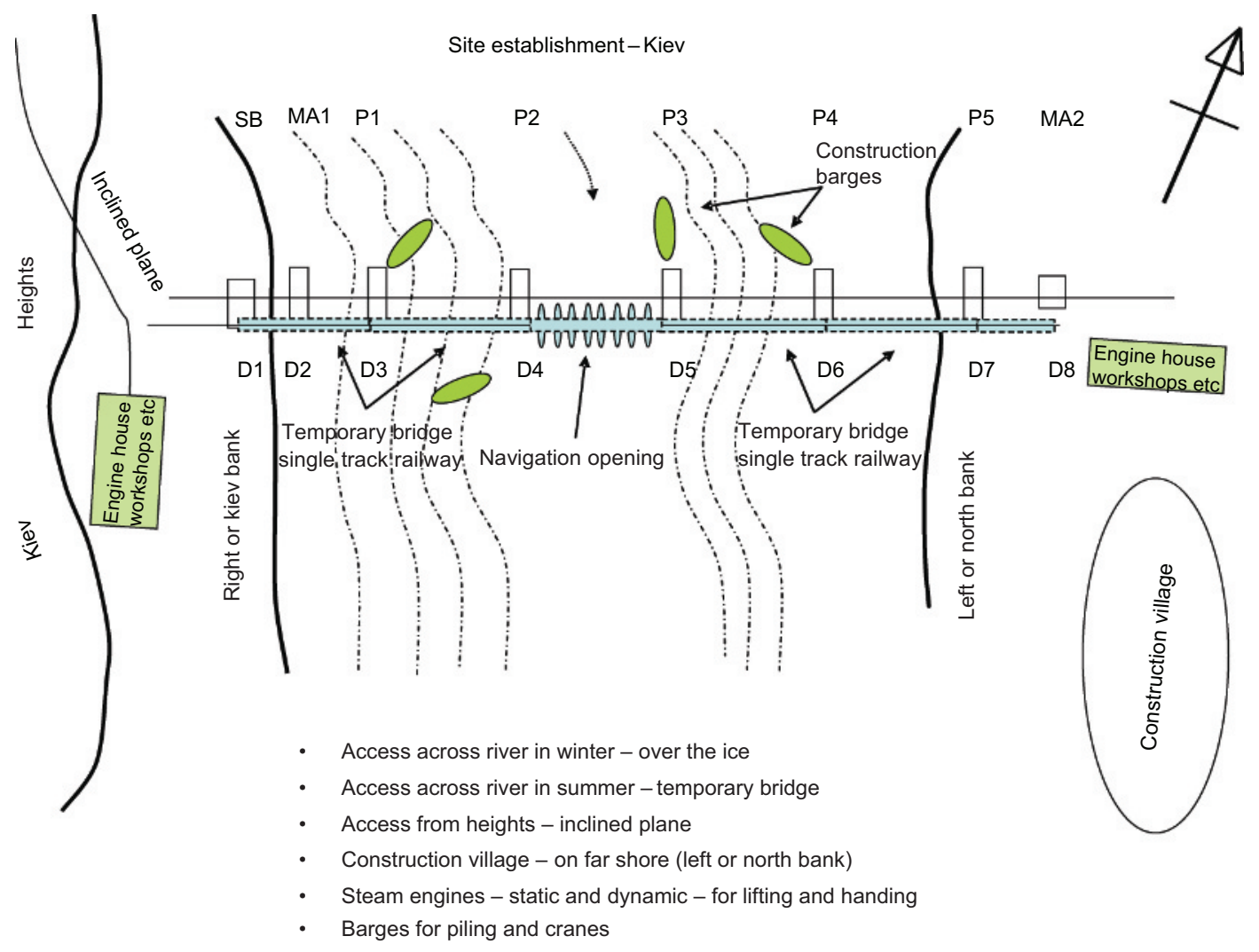

Figure 13. Layout of works at Kiev

congratulating him on the successful lift of the first Conway tube, and requesting his assistance with a parliamentary hearing on the North West Railway (Lancaster to Settle), as he could not leave Kiev at that time. He writes:

'The very large work I am engaged in here for the Emperor of Russia has nothing novel in it to the English Engineers. I have been busily engaged in matters which in this country require all my personal care and superintendance, but I am happy to say that except in magnitude, there are no difficulties to be encountered. It is chiefly a question of time and I am fortunate in having got an experienced and honest contractor. Of course, everything except Brick, Stone and Timber must come out from England, even leather and cordage, but I trust my arrangements to carry on everything smoothly and at present the season is favourable.' (Vignoles, 1848)

The first difficulties were, however, just around the corner. In mid-June cholera began to make its appearance. On 29 June, he notes in his journal 'much concerned to find that 100 men had left in consequence of apprehensions of the cholera, though epidemic on the decline.' The same day Vignoles noted that some of the temporary bridge piles had been broken during the night by barges and rafts travelling down the river. The contractor was reduced to borrowing soldiers from the garrison to man the piling engines. Sadly, on 2 July, $\mathrm{Mr}$ Whiteford, the engineering assistant from Ireland, was taken ill with cholera and died the same day.

Despite these difficulties, Vignoles returned to London in July, for a couple of months, leaving his son Hutton in charge, with instructions how to proceed. He took with him sufficient drawings and sketches to enable him to commission a largescale model (1:96) of the bridge from Mr Jabez James, a mechanical engineer who specialised in model-making, which he wished to present to the Tsar as an illustration of his bridgebuilding abilities. While in England, he took the opportunity to inspect the progress on the manufacture of the suspension chain links.

When Vignoles returned to Kiev in October, he found that considerable progress had been made in his absence - the temporary bridge was in use, the construction yard was prepared on the heights and the construction workers' camp on the other bank. He remained there during the next 6 weeks and his journal is full of examples of his leadership. 


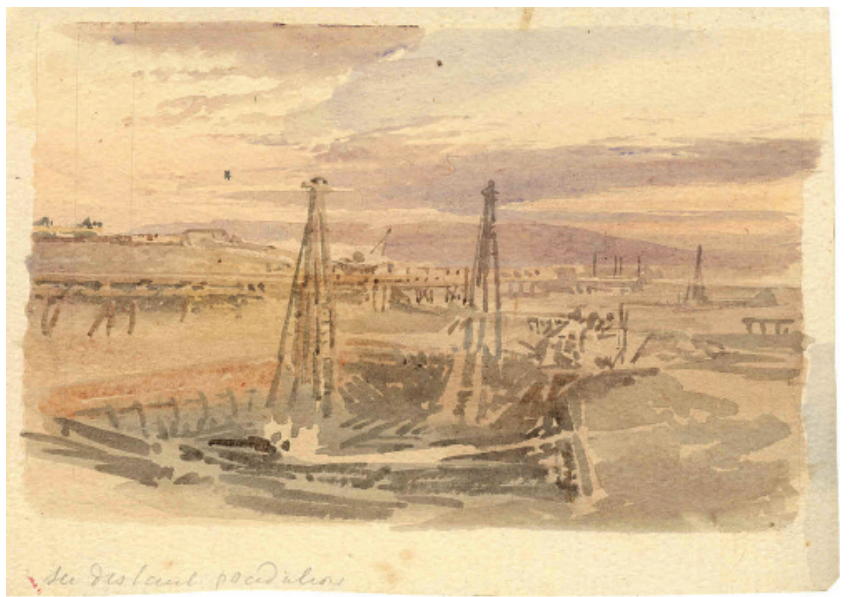

Figure 14. Piling in a foundation with temporary bridge beyond J.C. Bourne c. 1848 (Ironbridge Gorge Museum Trust)

On 18 October, after inspecting the completed deep water cofferdams, he noted in his journal that: 'The deep water cofferdams appeared to be well made and first trials of the engines and pumps showed that with a few alterations and more experience we should be fully in condition to meet all difficulties of water.' The water level at the time was $96 \mathrm{ft}$ (29 $\mathrm{m}$ ) above datum, significantly lower than it would be the following spring.

A month later (see Figure 15), there was a difficult moment when the river was partially frozen, which perhaps hinted at further problems for the next season. The river currents increased, the last river barges of the season swept down out of control and carried away a portion of the temporary bridge, much to Vignoles' fury. A few days later, Vignoles describes in his journal how, by dint of laying straw on the river surface, the remaining gaps between the ice floes were sealed and the works were closed down for the winter. Before leaving for London, he instructed the team to design and instal ice-breakers on the upstream side of each cofferdam and temporary bridge support in anticipation of the end of winter thaw.

\subsection{Forward planning}

Back in England in December, Vignoles found that the procurement of the chains was progressing, and the construction methods for the piers were being developed by William Coulthard. Meanwhile at Kiev, the engineers were set to work detailing the stones for the piers, and scheduling the timbers for the bridge deck to be put aside for seasoning.

\subsection{Interim payments}

In January 1849 came the first of many concerns regarding cash flow. Payments from Russia were not arriving at the required rate - he had had to make an advance of $£ 10000$ to Mr Blomberg in the summer - and to keep the flow of supplies and materials from England, Vignoles decided to take out a personal loan of $£ 15000$ from his solicitor. This decision was not taken lightly, but without it the work could not proceed, and he was determined not to let the production stall over something as basic as cash flow.

\section{Construction 1849}

When he returned to Kiev in the spring, Vignoles hoped that the works could proceed smoothly, but that was not to be the case.

\subsection{Setback on the riverworks}

The sequence of events is shown in Figure 16. In April 1849, as the river began to thaw, large ice floes collided with the piers of the temporary bridge causing damage to some spans, which had to be replaced. Then, to make matters worse, in May, the melting of the snow upstream caused the river to rise to a high flood level. A number of large timber barges were wrecked on the bridge works, causing yet more damage. The river continued to rise and 2 days later, with the water at $113.5 \mathrm{ft}$ (34 $\mathrm{m})$ above datum, a height of $19 \mathrm{ft}(6 \mathrm{~m})$ more than the previous summer, cofferdam D4 was swept away and cofferdams D3 and D5 were severely damaged.

In an extensive report to Colonel du Plat on 11 May Vignoles writes that: '...part of dam no 4 shot up vertically like a whale about 25 to $30 \mathrm{ft}$, and was carried away 2 versts downstream...' '...soundings show a water depth indicating 10 to $14 \mathrm{ft}$ of scour...' (Vignoles, 1849a).

Vignoles kept matters under control, securing cofferdams D3 and D5 by sinking barges on top of them as ballast. After taking soundings for scour and inspecting piles salvaged from the wreckage of cofferdam D4, he gave instructions to the site staff to redrive the cofferdams with three concentric rows of longer length piles, and to fill between the walls with puddle clay.

Two days later, Vignoles left for England via Warsaw for a typically busy few weeks. He attended the ICE when Thomas Howard presented his paper on rolling bars for suspension bridges (Howard, 1849); he visited the Britannia Bridge tubes at Bangor, which had been installed by Robert Stephenson while he was out of the country; and he visited Coulthard to discuss the swing bridge designs, which were to incorporate wrought iron beams.

While at Bangor, Vignoles discussed the problems of river scour with I.K. Brunel, Robert Stephenson and William Cubitt, among others. He also consulted with Herr Hubbe, the Hamburg Port Authority engineer, who advised the use of fascine mattresses. After viewing an installation in Holland, Vignoles appointed two Dutch engineers to come to Kiev and 


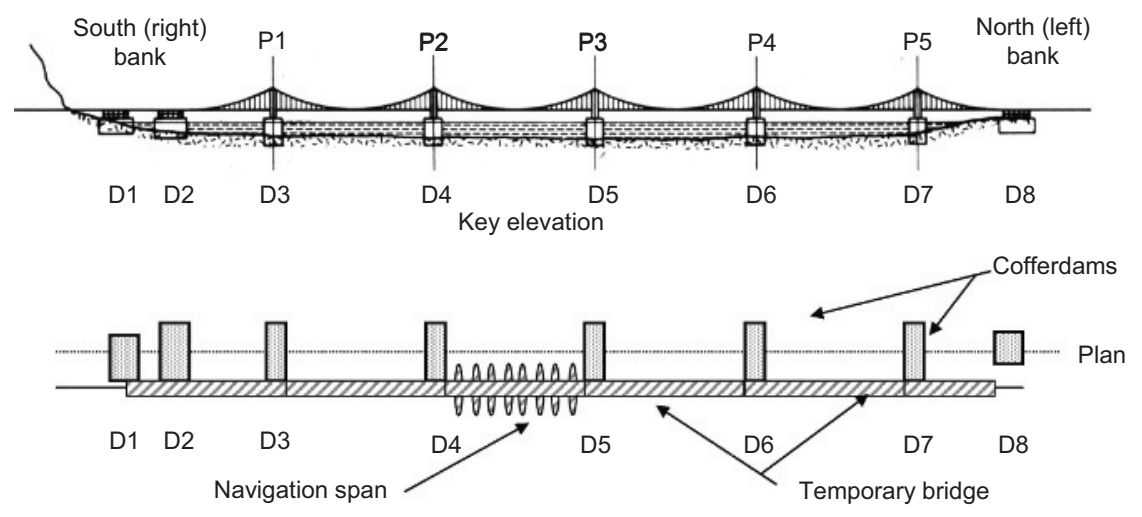

October 1848 - Piling to cofferdams and temporary bridge complete

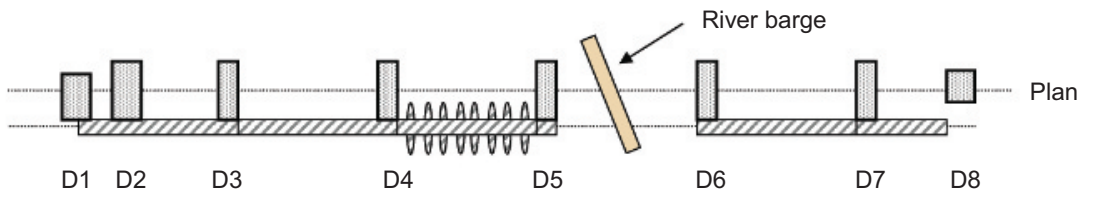

November 1848 - Span of temp bridge destroyed by barges

Figure 15. River works in 1848

reinforce the river bed against scour around the cofferdams with willow mattresses. In the first part of August he was present in Ireland for Queen Victoria's visit to Dublin. On 16 August, he was back in London leaving for Warsaw via Hamburg and Berlin, and was finally back in Kiev on 5 September.

By the end of October 1849, the cofferdams were securely remade at last, the river bed reinstated and the fascine mattresses laid (see Figure 17). However, the project was now effectively a year behind schedule.

\subsection{Inclined plane experiments}

In October 1849, Vignoles carried out a series of experiments to see if the operation of the inclined plane could be automated, using empty wagons as counterweight. The incline consisted of two gradients of 1 in 14 and 1 in 4, separated by a curve in plan. To overcome the friction in the pulleys, it was shown necessary to use five loaded wagons to recover one empty one. Vignoles notes in his journal:

'I conclude that the number of waggons and the number of men to work the plane from the top of all is too great... we have to... place [the large wheels] on the top of the steep part of the plane [1 in 4 gradient] and work the upper part by letting the loaded waggons down the 1 in 14 with the brake and pull up the empty waggons with horses; paving between the rails.' (Vignoles, 1849b)

\subsection{Erection of scale model in St Petersburg}

In December 1849, Vignoles went to St Petersburg to supervise the erection by Mr Jabez James and his colleagues of the 1:96 scale model, which he had commissioned the year before. The $26 \mathrm{ft}(8 \mathrm{~m})$ long model, complete in every particular, was installed in the Winter Palace and presented to Tsar Nicholas I by Vignoles on his 'name-day'. To celebrate the model's completion, the article describing the works was published in The Times on Wednesday 2nd January 1850, and copied to the Mechanics Magazine 3 days later (The Times, 1850). The model is still in the Museum of Railway Transport in St Petersburg and has thus outlasted the bridge itself.

Vignoles commissioned a duplicate copy of the model, which was exhibited adjacent to one of Stephenson's Britannia Bridge at the 1851 Great Exhibition (Great Exhibition, 1851). In 1854 it was placed in the permanent exhibition at the relocated Crystal Palace in London (where it was destroyed in a fire in 1866). The text of The Times article of 1850 was used as the basis for the brochure narrative (Vignoles, 1854).

\section{Work on site $\mathbf{1 8 5 0}$ and $\mathbf{1 8 5 1}$}

Early in 1850, there was more concern about expenditure. It was decided to abandon the domestic set-up as it was too expensive, and to send his daughter Camilla home. The site establishment would then be run as part of the office, and the finances managed accordingly. 

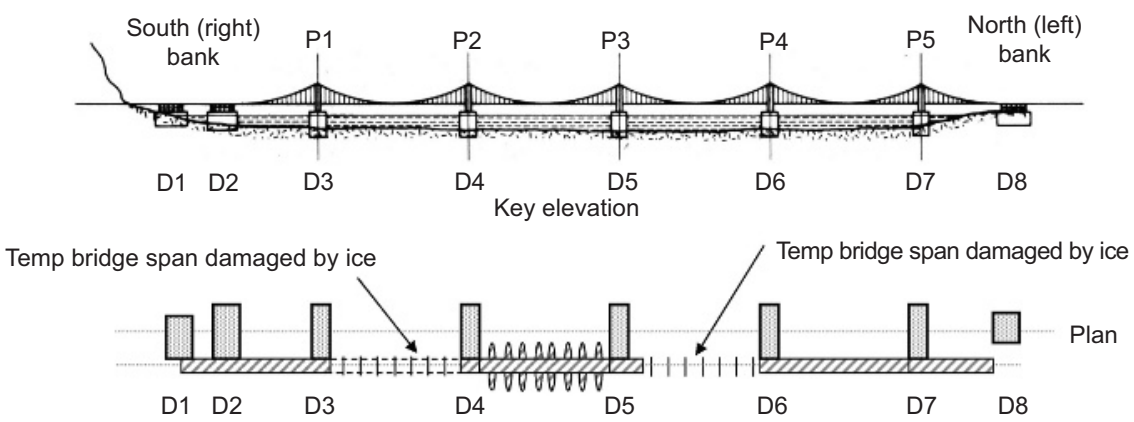

April 1849 - ice damage

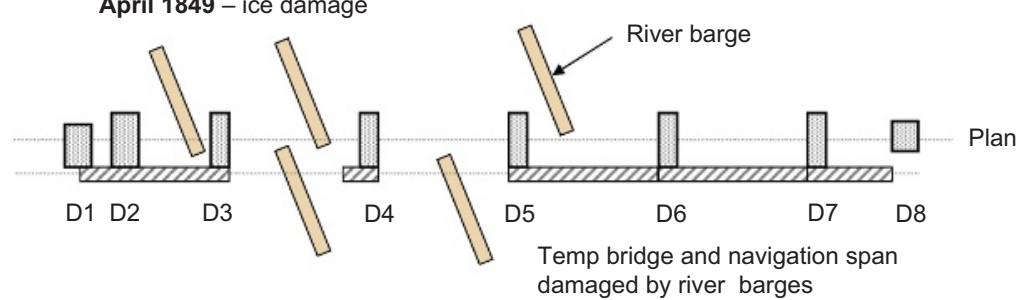

May 1849 - barge damage

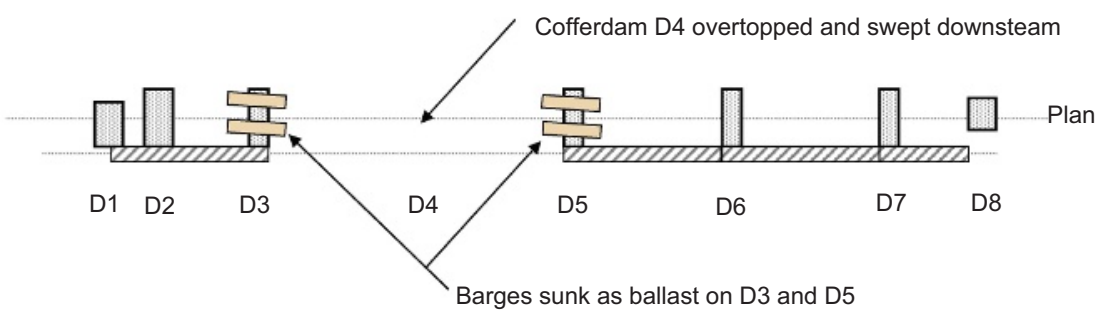

May 1849 - Flood damage

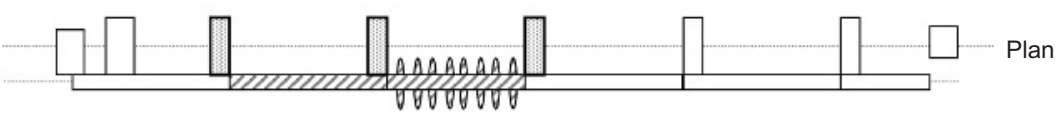

D1 D2 D3

D4 D5

D6

D7 D8

Aug - Oct 1849 - Cofferdams and temporary bridge reconstructed

Figure 16. River works in 1849

When the thaw of 1850 came, work could once again restart on the cofferdams. Now the construction plant came into its own. There were two static steam engines, one on each bank, and five mobile ones. The cofferdams were pumped down, the leaks plugged, and attempts made to bottom them out with a mixture of clay puddle and concrete. The cement for the concrete was made in the yard, where there were eight large roasting ovens, capable of producing $500 \mathrm{ft}^{3}\left(14 \mathrm{~m}^{3}\right)$ of cement each day (Vignoles, 1854).

During the summers of 1850 and 1851 the work dragged on and the project became further behind schedule. There were big problems with water leaks in the bases of the cofferdams, and much working time was lost because of saints days and holidays. As a consequence, there was little progress during the summer of 1850 with the bases of D3, D4 and D5, and at this time Vignoles took personal charge of work on site in an effort to speed progress. As a result of his efforts, the bases of the shallow water foundations, in dams D6 and D7, were concreted before the winter of 1850 closed in, and work on the bases to piers P4 and P5 could at last begin (see Figure 18).

In October 1850, potential disaster struck again when the main contractor, $\mathrm{Mr}$ Blomberg, died. Fortunately for 


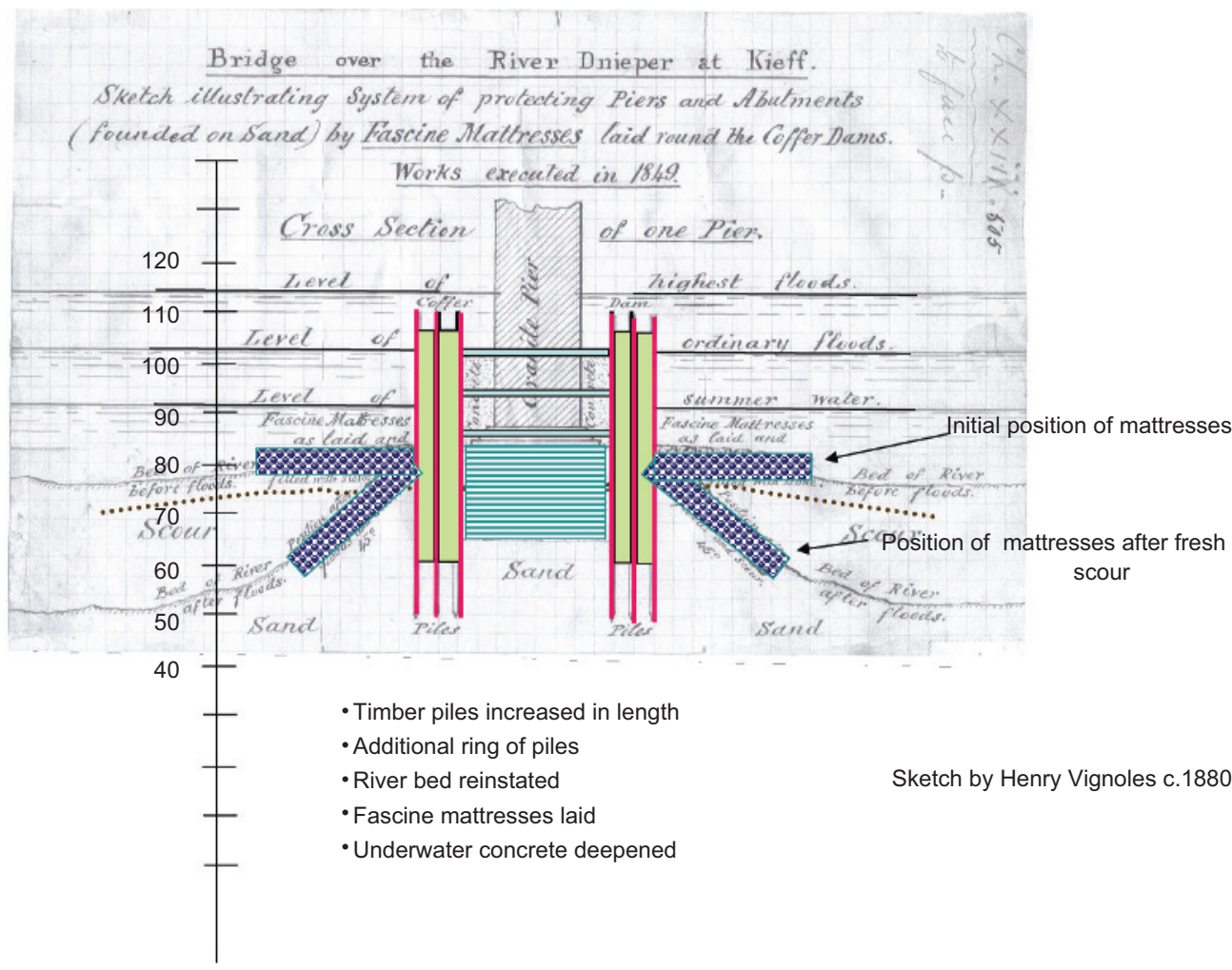

Figure 17. Details of redesigned cofferdams, based on a sketch by Henry Vignoles (c. 1880)

Vignoles, the agent on site, Mr Schweitzer, agreed to carry on the work.

In the Spring of 1851, work recommenced on the deep water foundations, and by the end of the season much progress had somewhat belatedly been made (see Figure 19). The deep water cofferdams were finally sealed by mid-September, the foundations completed, and the piers (P1, P2 and P3) were built to above flood level. Piers P4 and P5 had by then been completed up to arch level, which enabled Vignoles to indicate the position of the suspension chains, when the Tsar visited the site, by arranging to hang ropes between P4, P5 and the abutment.

Work could then continue through the winter on completing the portals to piers 1,2 and 3 .

Figure 20 is a drawing 'in colour by candlelight' by Bourne showing the construction of a pier in October 1851. Points of interest are the centering of the arch, the saddles for the chains and the temporary works platforms. At the right of the picture can be seen the temporary bridge.

\section{Chain lifting and deck construction 1852 to 1853}

\subsection{Chain lifting}

Commencing in June 1852, the suspension chains were now erected on a span-by-span basis (see Figure 21). This involved positioning trestles at points along the span and using block and tackle to winch the chains up to level. A fair amount of supervision was needed for this, and there are frustrated remarks in Vignoles' journal about the time it took and the skills required. The deep water chains would be lifted during the winter while the river was frozen, using trestles placed on the ice.

In August 1852, the photographer Roger Fenton travelled to site with Vignoles, bringing his stereoscopic camera equipment with him (Hannavy, 2004).

Three photographs by Fenton record the chain erection process. Figure 22, which is taken from a larger photograph, shows chain erection starting on pier number 1 . The inclined plane can be clearly seen in the background. 

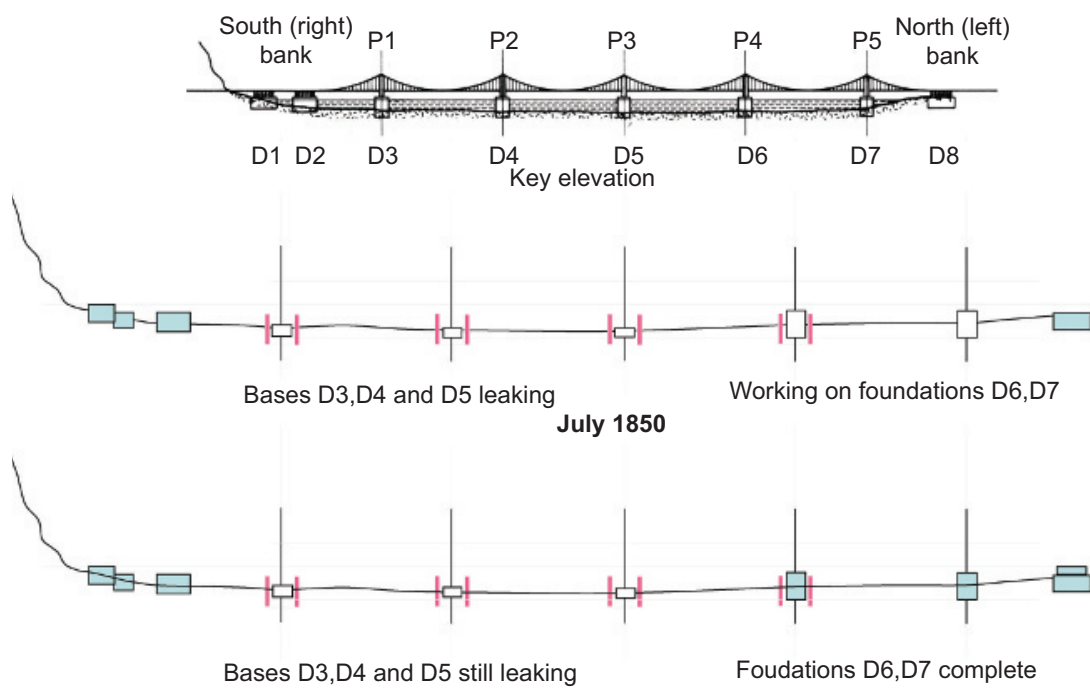

November 1850

Figure 18. Foundation sequence 1850

Figure 23 shows chain erection on pier numbers 4 and 5 . Figure 24 shows details of the chain erection process. The last two are composite images prepared from photographs in the collection of Dom Pedro II of Brazil at the National Library in Rio de Janeiro.

\subsection{Deck construction 1853}

Once the chains were in place, the deck construction could follow unimpeded by the river (see Figure 25) and the project could at last be brought to a successful conclusion.
There was again concern about cash flow. To cover outstanding payments, Vignoles used a life insurance as security to raise a further $£ 17000$. He brought a significant amount in gold coin with him personally to pay the workforce, when he travelled to site in August 1853, this being the simplest way of providing it.

\subsection{Acceptance trials}

At the end of September 1853, as part of the acceptance trials, the bridge was test-loaded (see Figure 26). The bridge spans

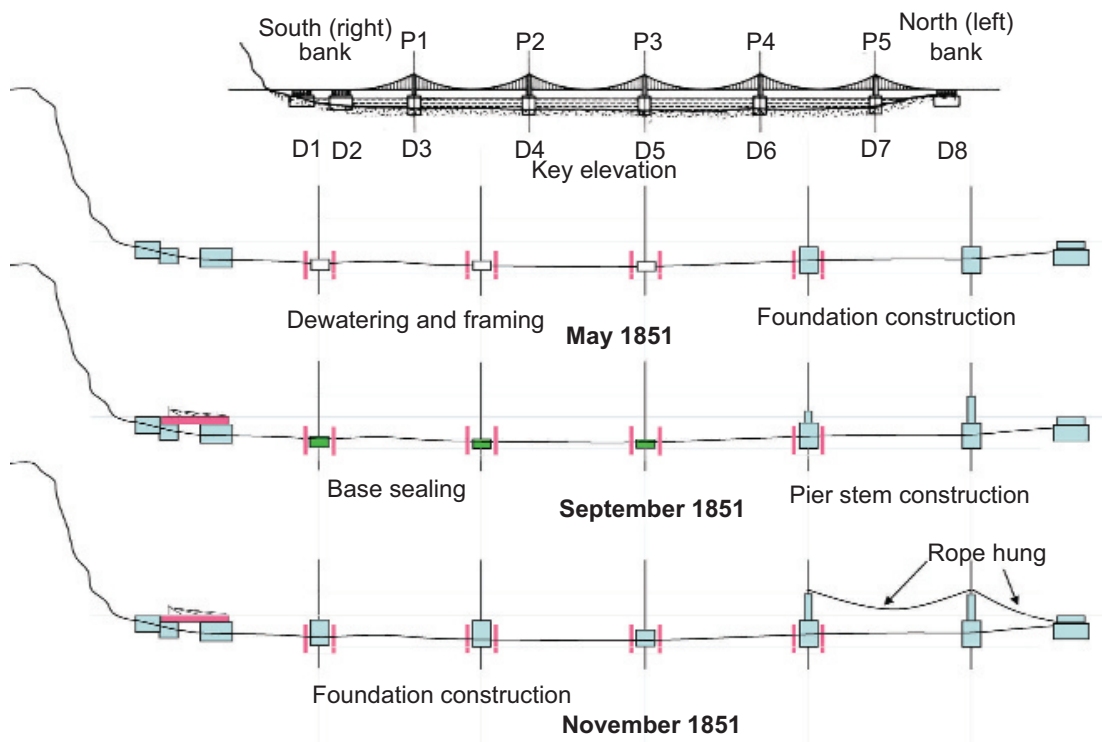

Figure 19. Foundation sequence 1851 


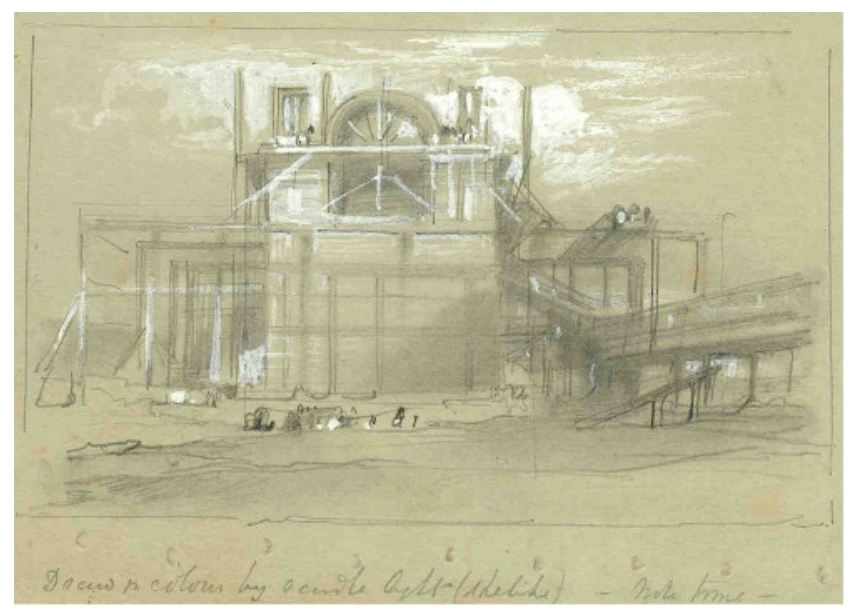

Figure 20. Pier construction - J.C. Bourne, October 1851 (Ironbridge Gorge Museum Trust)

were loaded with $60000 \mathrm{ft}^{3}\left(1698 \mathrm{~m}^{3}\right)$ of sand, which was brought in by the barrow-load (see Figures 27 and 28). Before the spans were fully unloaded a heavy rainstorm ensued, which soaked the dry sand, increasing the effect of the load considerably. Although being alarmed at the possible effects of this, Vignoles was relieved to note that the bridge stood the strain sucessfully 'with a load equal to 40,000 men' - revised to 50000 men in Table 2 - and that 'there was no permanent deflection in the bridge platform nor any stretch in the chains'.

\section{Completed bridge}

\subsection{Opening}

Finally, on 10 October 1853 the bridge was opened by Grand Duke Nicolas, the third son of Tsar Nicholas I. There was a full ceremony of blessing and crowds thronged the bridge (Figure 29).

A week later, Vignoles disbanded his establishment and left Kiev never to return. A skeleton staff remained to deal with outstanding items, carry out the maintenance, and draw up the final account, finally returning to England in 1855.

\subsection{Accounts}

Vignoles published an impressive set of statistics to accompany the scale model in the 1854 Great Exhibition at the Crystal Palace (see Table 2). This gives the final cost of the bridge project as approximately $£ 432000$ (Vignoles, 1854).

Unfortunately for Vignoles, given the huge quantity of personal funds he had invested in the project, the account was not settled until after the end of the Crimean War. He spent some months in St Petersburg pursuing outstanding payments both for his unfulfilled designs and for the bridge itself. In January 1858, he received a final payment in part settlement of his claims. In February 1858, there is a note in the journal regarding settling the accounts of $\mathrm{Mr}$ Palmer, his solicitor, Mr Coulthard, his design assistant, and Mr Bourne, his photographer. In March 1858, he notes that he has: 'sent to Douglas Evans at his request a discharge in full... signed by

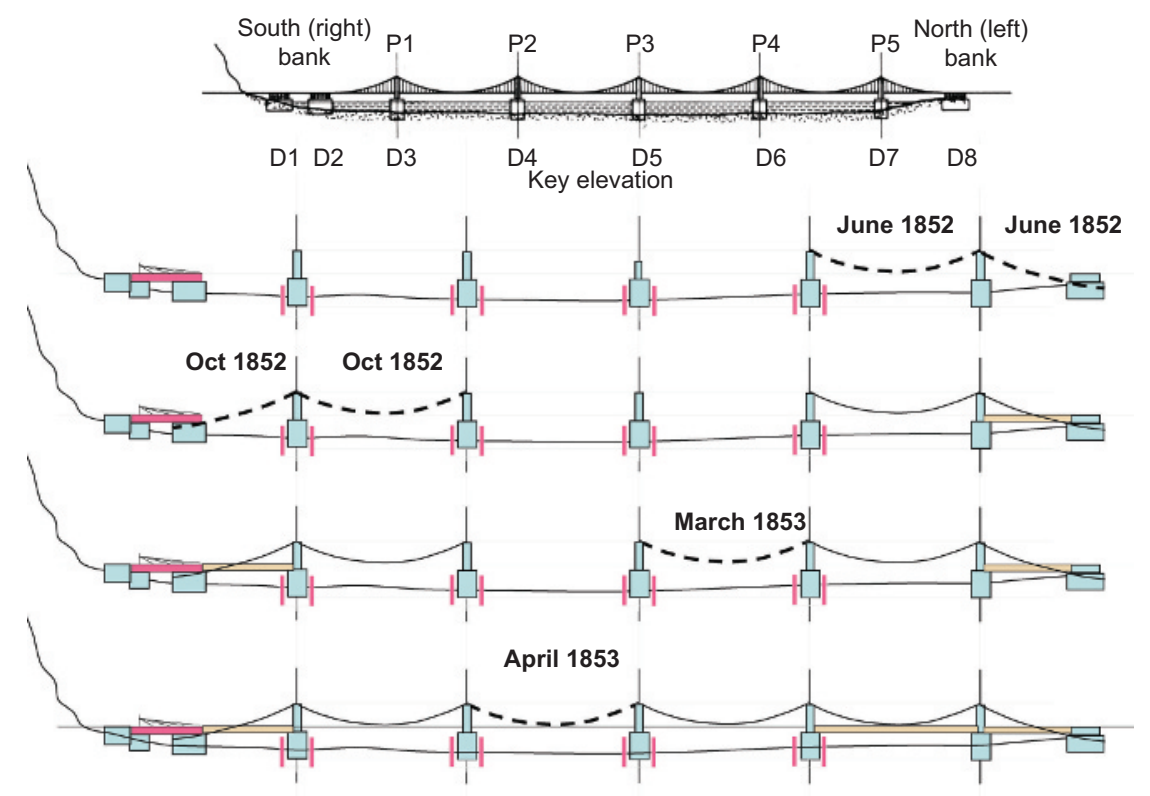

Figure 21. Deck sequence 1852 to 1853 
Engineering History and Heritage

Volume 165 Issue EH1
The construction of the Kiev

Suspension Bridge 1846-1853

Vignoles

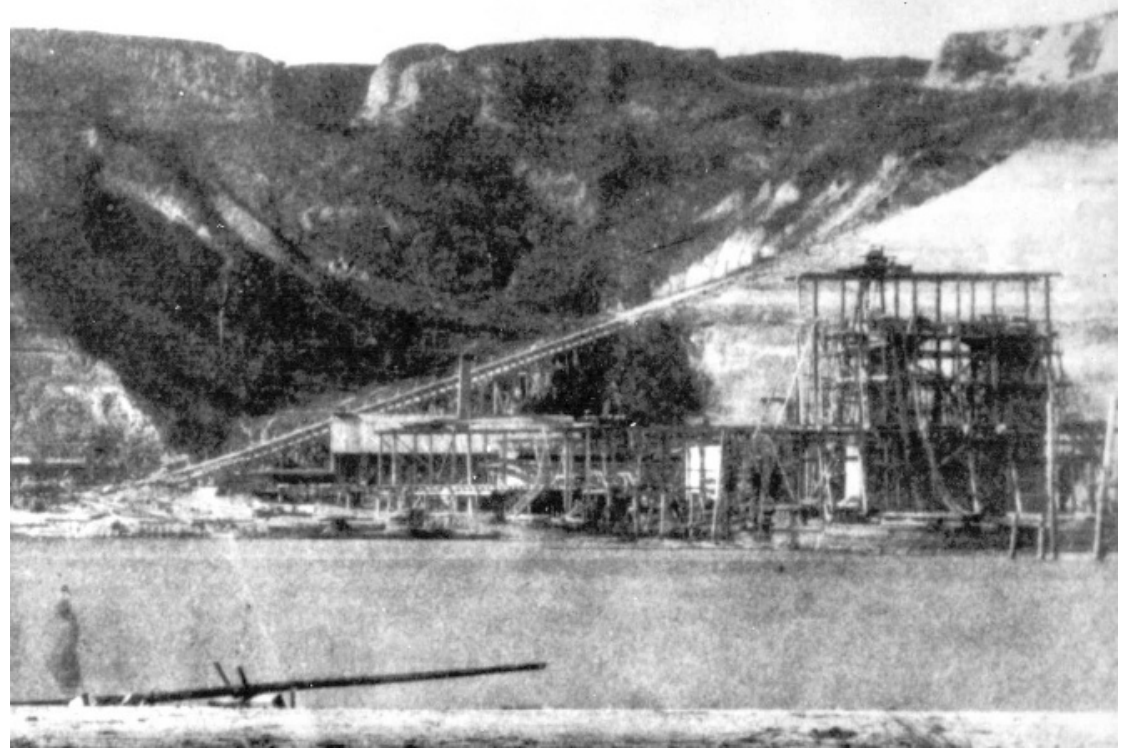

Figure 22. Chain erection on pier no. 1 - detail from a photograph by Roger Fenton, September 1852 (Royal Photographic Society Collection at the National Media Museum, Bradford)

me, releasing him from further [liability] for all sums on Kieff a/c which had passed through his hands since 1848 '.

\subsection{Legacy}

Notwithstanding the difficulties in its construction, the Tsar Nicholas 1 Bridge stood for many years (see Figure 30). However, in 1920 the bridge deck was destroyed by the retreating Polish army, and the crossing reverted to a bridge of boats. In pictures of the destroyed bridge willow tree growth from the fascine mattresses can be clearly distinguished.
A new deck was constructed at a higher level using the original piers, which were still valid. This bridge was destroyed in 1941 . The foundations can just be made out at low water alongside the modern metro crossing.

\section{Conclusion}

Back in London, free from the burden of such an ambitious project, Vignoles concentrated on overseas railway work on the Rhine; by Lake Geneva; in Bahia in Brazil, where he was represented by his son Hutton; in Spain; and in Poland.

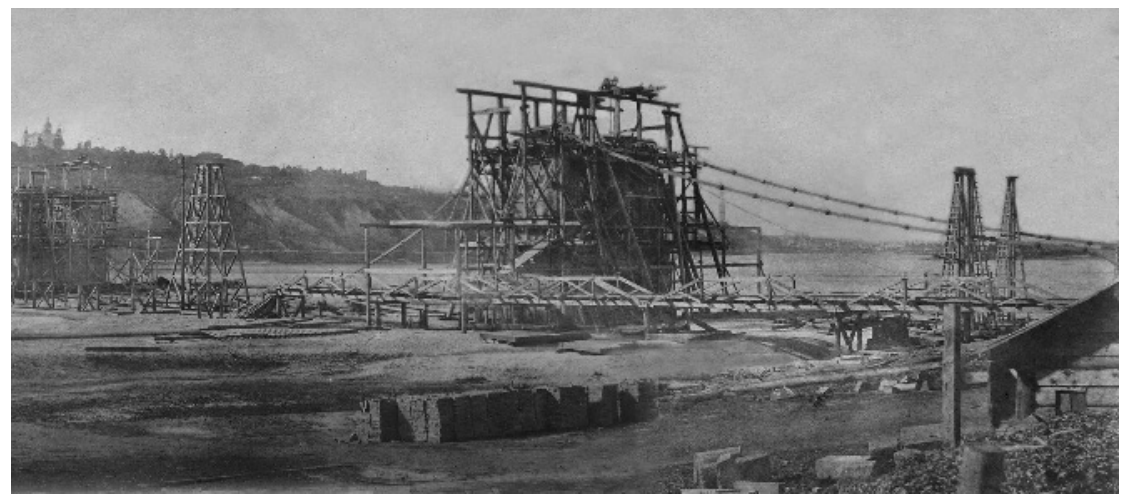

Figure 23. Chain erection piers 4 and 5 - from photographs by Roger Fenton, 1852 (Acervo da Fundação Biblioteca Nacional, Brasil) 
Engineering History and Heritage

Volume 165 Issue EH1
The construction of the Kiev

Suspension Bridge 1846-1853

Vignoles

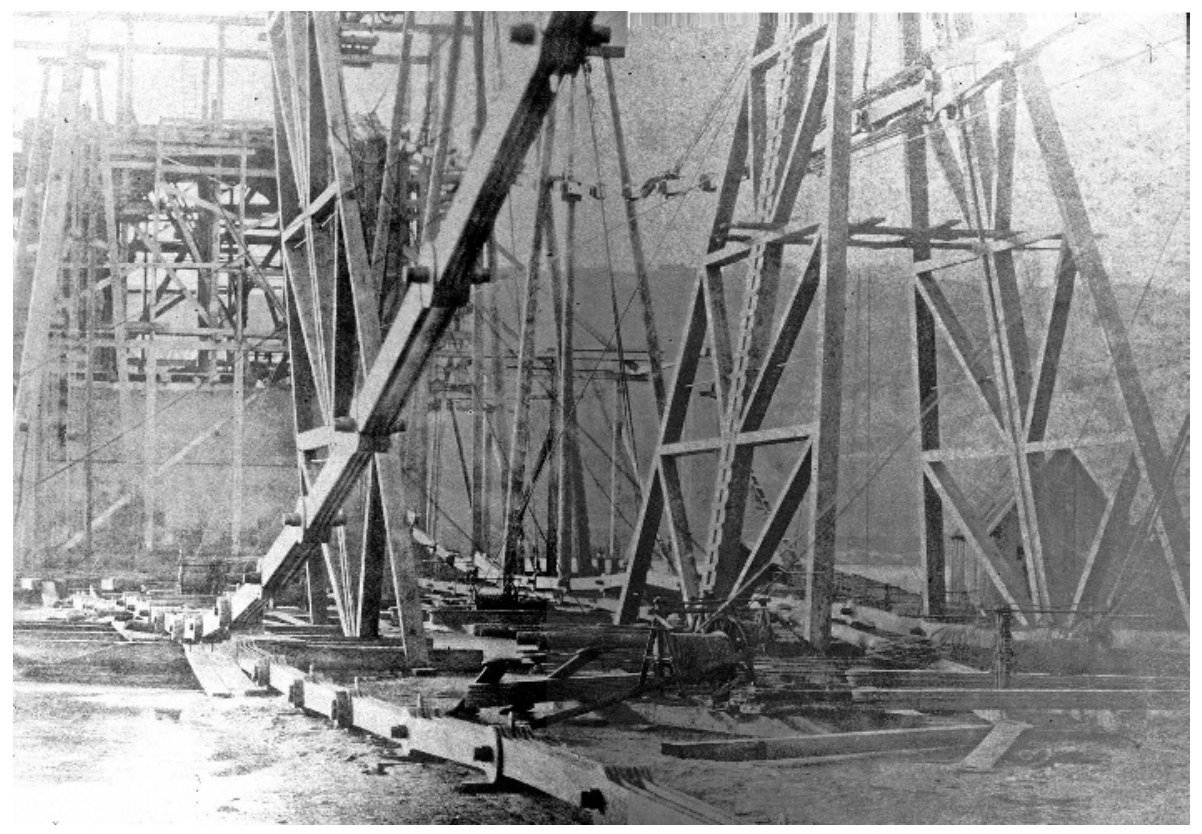

Figure 24. Details of chain erection - from a photograph by Roger Fenton (att), 1852 (Acervo da Fundação Biblioteca Nacional, Brasil)

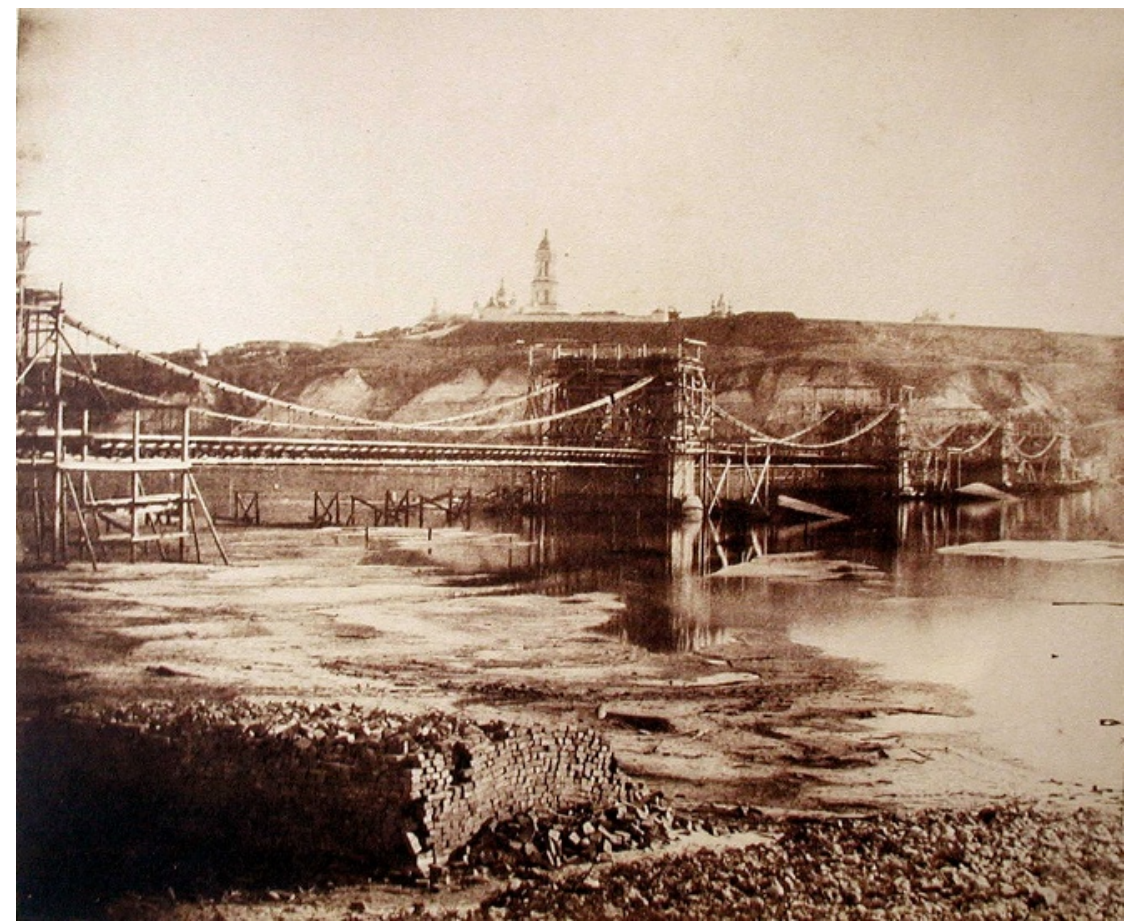

Figure 25. View of deck under construction - J.C. Bourne, 1853

(collection of National Museum of the History of the Ukraine, Kiev) 
Engineering History and Heritage

Volume 165 Issue EH1
The construction of the Kiev

Suspension Bridge 1846-1853

Vignoles
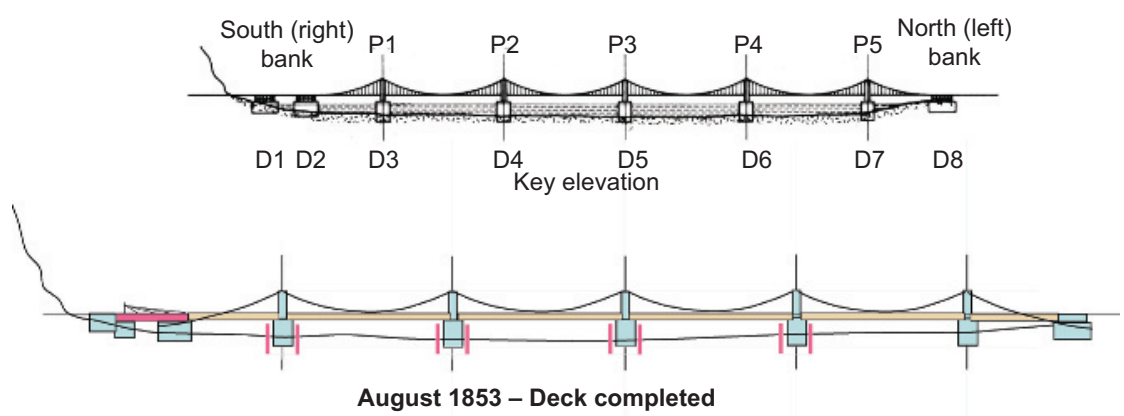

$\begin{array}{ccccccr}\text { Test A } & 300 \text { tons } & 600 \text { tons } & 600 \text { tons } & 600 \text { tons } & 600 \text { tons } & 300 \text { tons } \\ \text { Test B } & 0 \text { tons } & 0 \text { tons } & 0 \text { tons } & 0 \text { tons } & 400 \text { tons } & 0 \text { tons }\end{array}$

Test $\mathrm{A}-60,000 \mathrm{cu} \mathrm{ft}$ wet sand equals 3000 tons Test $\mathrm{B}-400$ tons on span $\mathrm{P} 4-\mathrm{P} 5$ remainder unloaded. No significant deflection

September 1853 - Test loading

10 October 1853 - Opening ceremony

Figure 26. Completion testing $1853(1 \mathrm{cu} \mathrm{ft}=1$ cubic foot $=$ $0.0283 \mathrm{~m}^{3} ; 1$ ton $=1.01604$ metric tonnes)

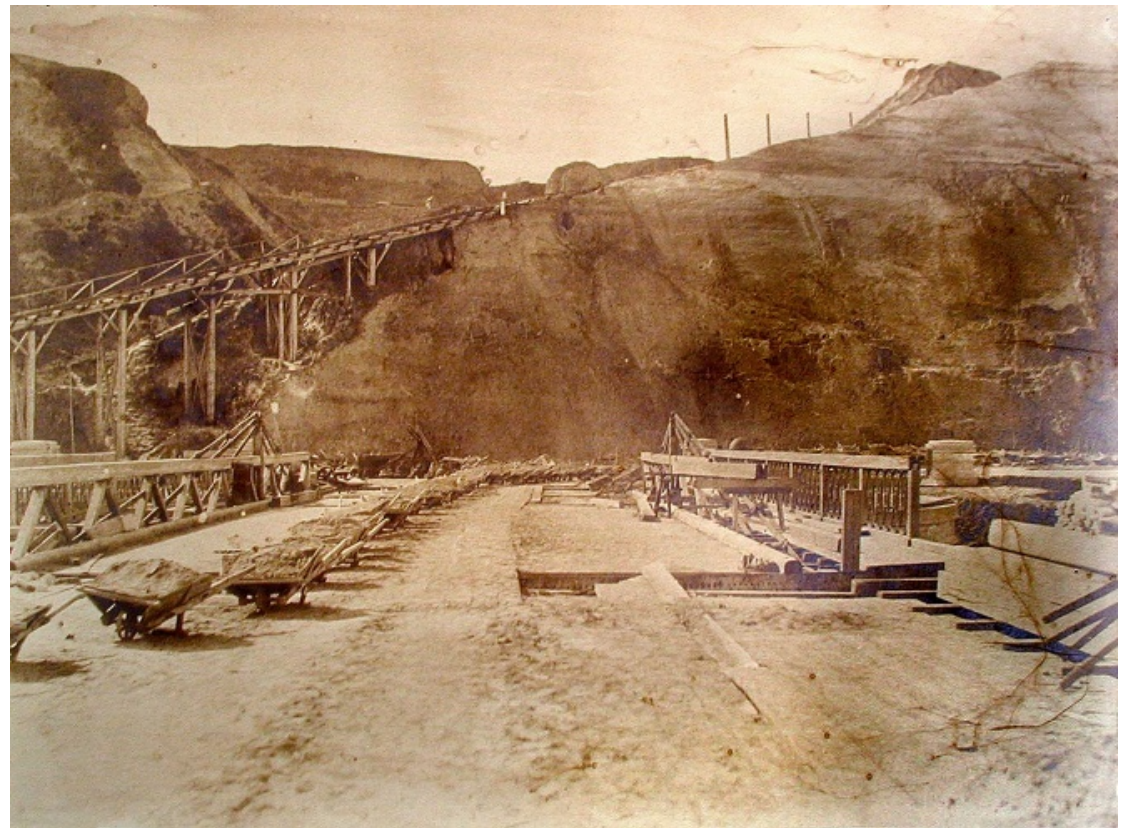

Figure 27. Test loading - sand barrowed in over the swing bridge J.C. Bourne, 1853 (collection of National Museum of the History of the Ukraine, Kiev) 
Engineering History and Heritage

Volume 165 Issue EH1
The construction of the Kiev

Suspension Bridge 1846-1853

Vignoles

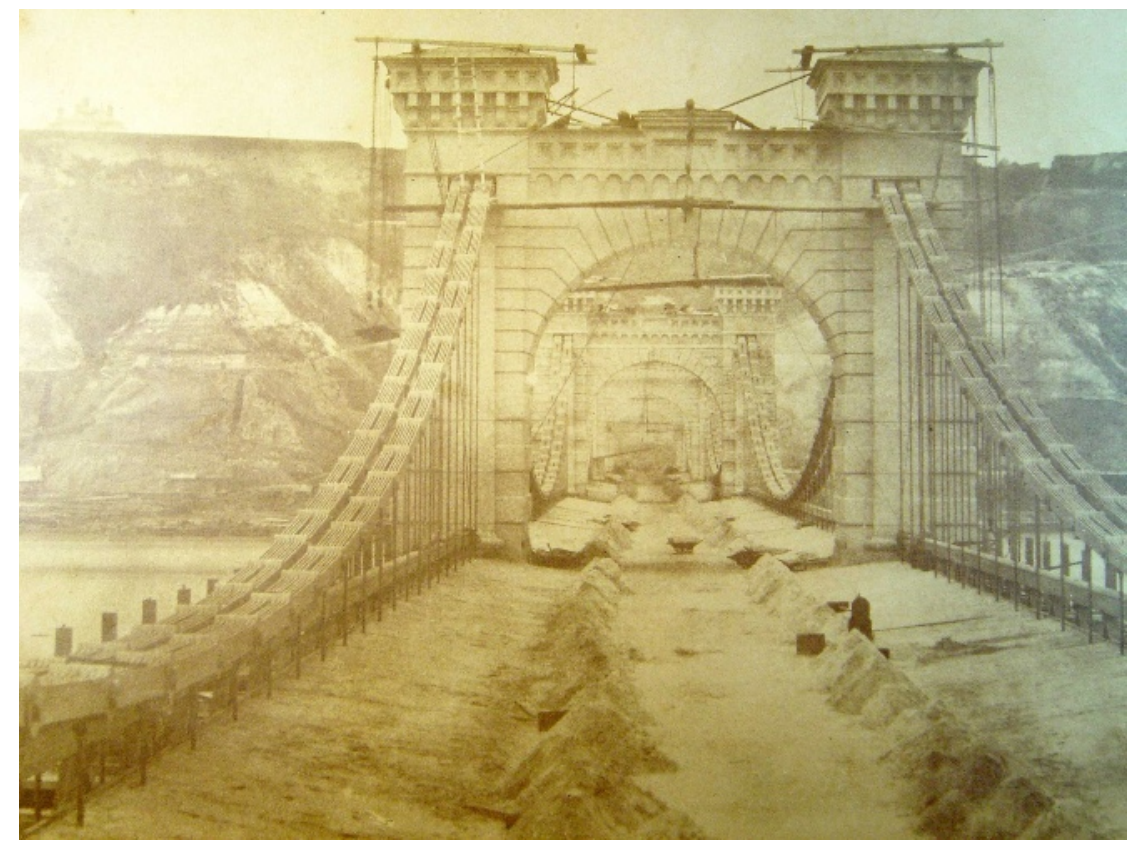

Figure 28. Test loading - sand being spread over the main bridge deck - J.C. Bourne, 1853 (Acervo da Fundação Biblioteca Nacional, Brasil)

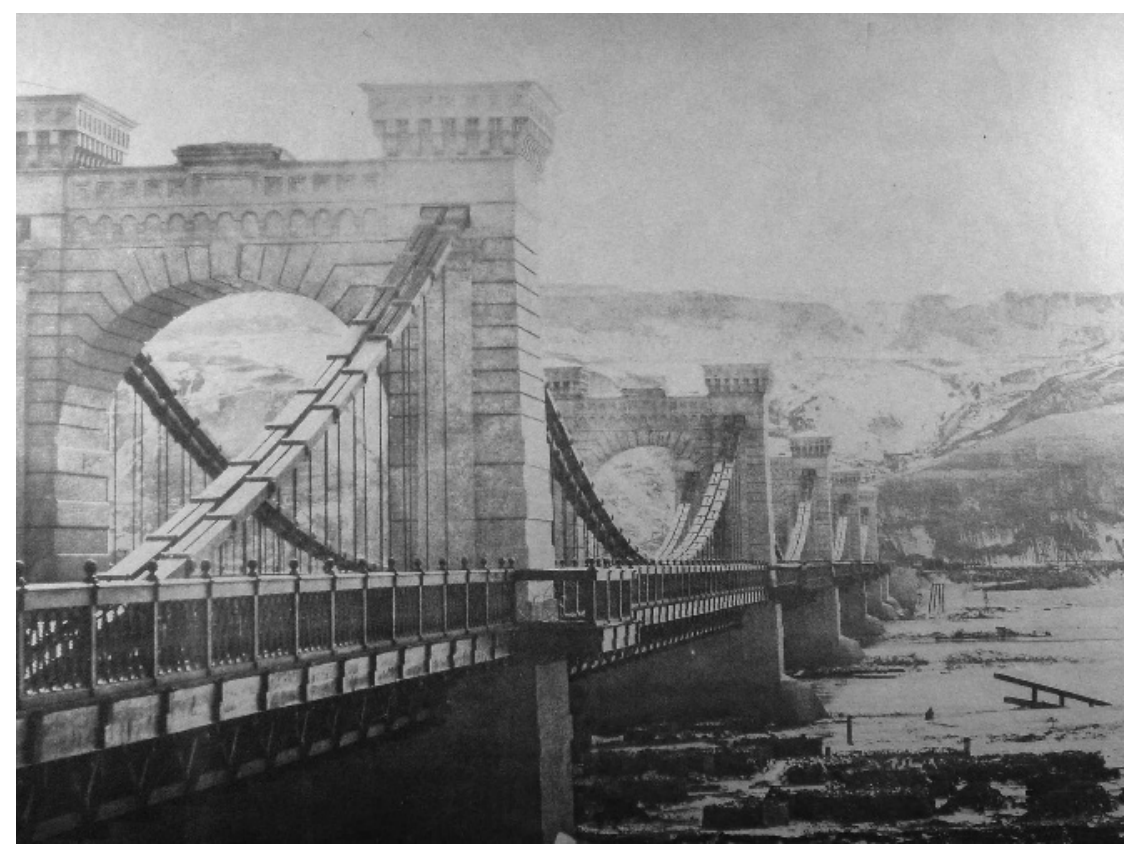

Figure 29. Completed bridge - J.C. Bourne, 1853 (private collection) 


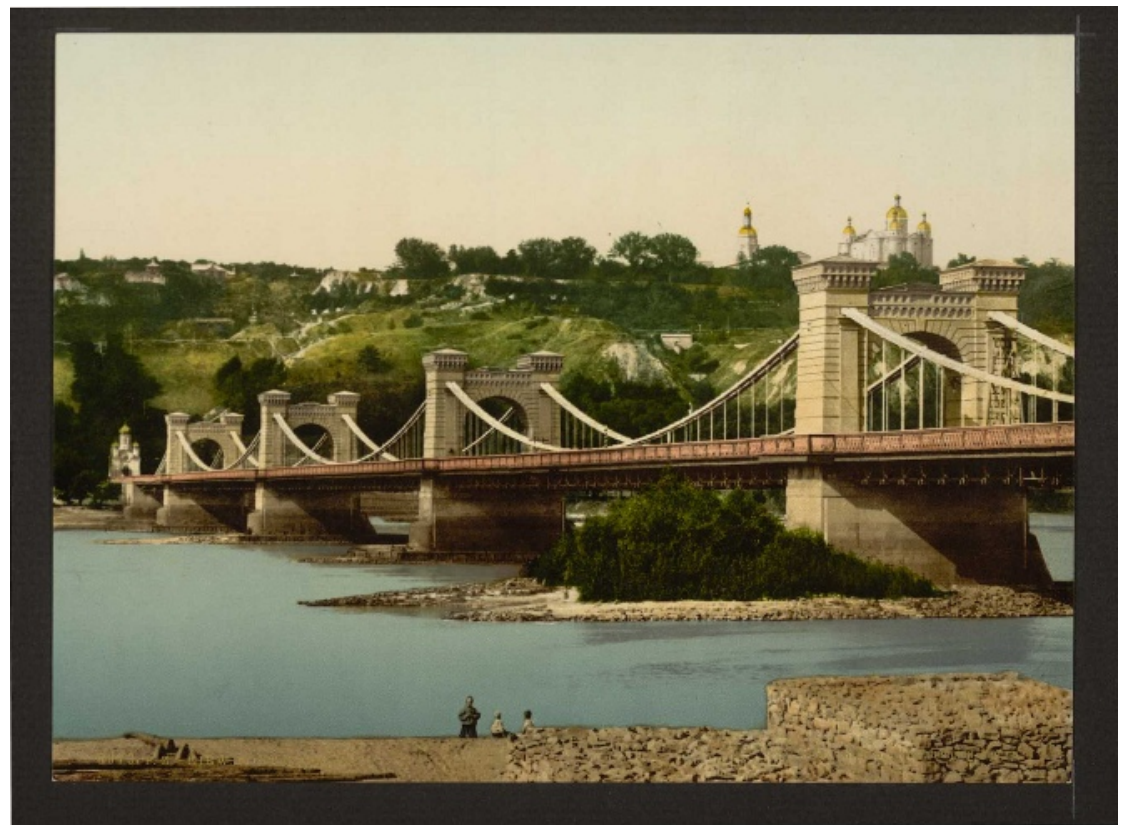

Figure 30. Kiev Bridge in c. 1890-1900 (Library of Congress

photochrom print collection no. 03819)

He continued his interest in photography, and when in London he found time to attend ICE discussions on many subjects; also his name lives on in the flat-bottomed rail that bears his name. But perhaps surprisingly, given the scale of the project, although details of the Kiev Bridge construction were alluded to in various papers to the ICE and also to the British Association for the Advancement of Science (Vignoles, 1857), the promised technical paper, which at one time was planned for 1855, never materialised. As Vignoles commented during a discussion (ICE, 1867) 'procrastination is the thief of time' - the only published piece of writing being The Times article, the exhibition catalogues and the 1854 brochure. Part of the purpose of this paper is to set the record straight.

The story of the building of the Kiev Bridge brings out the character of Charles Blacker Vignoles in many ways. His determination to take on such an ambitious venture, his perseverance to see it through, his willingness to take risks with his own money, his ability to stimulate and enthuse his team of assistants, his pride in his workmanship, his wide knowledge and interest in every aspect of engineering, his showmanship and feeling for publicity - these qualities are all typical of the man and indeed of the age. Similar examples are to be found time and again in his journals, demonstrating that he was indeed a worthy member of the engineering fraternity. This was recognised when he was elected President of the ICE from 1869 to 1871 .
His life's work complete, Vignoles died in 1875 at the age of 82 years. The Kiev Bridge survived him for 45 years.

\section{Acknowledgements}

This paper arises primarily from research carried out by the author using notes prepared by his father K.H. Vignoles for his 1982 biography of C.B. Vignoles. The author also wishes to acknowledge the assistance of Mike Chrimes and his staff at the ICE, and also of John Hannavy, who generously shared his work on Fenton and Bourne. Previous versions of this paper were given at the Construction History Conference in 2006 and at the Advanced Bridge Engineering Conference in 2006 (Vignoles, 2006a, 2006b).

\section{MANUSCRIPT SOURCES}

In preparing the paper, the author made extensive use of Vignoles' unpublished journals and diaries, which are in The British Library. These are listed in the Additional Manuscripts collection catalogue as

Journals of Charles Blacker Vignoles (eight volumes comprising Add. ms 34528 to 34535, Add. ms 35071) Vol. III 1842-1845; Vol. IVa 1847-1848; Vol. IVb 1849-1850; Vol. V 1851-1853; Vol. VI 1854-1856; Vol. VII 1857-1859.

- Vignoles Diaries (four volumes comprising Add. ms 58203 to 58206) Vol. III 1846; Vol. IV July-November 1851.

Vignoles' unpublished letters are held in the Portsmouth Records Office as Letters of Charles Blacker Vignoles (ref. 1072A). 


\section{REFERENCES}

Chrimes M (1997) Civil Engineering 1839-1889 - A Photographic History, 2nd edn. Budding Books, Stroud.

Clark WT (1852) An Account of the Suspension Bridge across the River Danube Linking Pesth with Buda. John Weale, London (in the ICE Library).

Cross-Rudkin PMS, Chrimes MM, Bailey MR et al. (2008)

Biographical Dictionary of Civil Engineers in Great Britain and Ireland. Volume 2: 1830-1890. Thomas Telford, London.

Fox C (1865) On the size of pins connecting flat links on the chains of suspension bridges. Proceedings of the Royal Society XIV: 139-144.

Great Exhibition (1851) Official Descriptive and Illustrated Catalogue of the Great Exhibition 1851. Vol. 1, pp. 320-321.

Hannavy J (2004) John Cooke Bourne, Charles Blacker Vignoles and the Dneiper Suspension Bridge at Kyiv. History of Photography 28(4): 334-347.

Howard T (1849) Description of method of rolling bars for suspension bridges and other similar purposes and following discussion. Proceedings of the Institution of Civil Engineers 8(1849): 273-281.

Institution of Civil Engineers (ICE) (1867) Suspension bridges of great span. Proceedings of the Institution of Civil Engineers 26(1867): 270-271.

Johnson W (1869) The Practical Draughtsman's Book of Industrial Design, 3rd edn. E \& FN Spon, London, pp. 178 and 179 , plate 45 .

Maude TJ (1841) Account of alterations made in the structure of the Menai Bridge.... Institution of Civil Engineers Transactions 3(5): 371-375.

Rendel JM (1841) Memoir of the Montrose Suspension Bridge. Proceedings of the Institution of Civil Engineers 1(1841): 122-129.

Riddle E (1852) American Commissioner to the Great Exhibition, report in Report of the Commissioner of Patents, United States Patent Office. pp. 346-437; 465-466.
Skempton AW, Chrimes MM, Cox RC et al. (2002) Biographical Dictionary of Civil Engineers in Great Britain and Ireland. Volume 1: 1500-1830. Thomas Telford, London.

Smith D (1991) The works of William Tierney Clark. Newcomen Society 63: 181-207.

The Times (1850) Great Suspension Bridge in Russia. Wednesday, 2 January 1850, issue 20375, col. E, p. 8.

Vignoles CB (1847) Journal of Charles Blacker Vignoles Volume IVa (1847-1848). British Library Additional Manuscripts collection ref. Add Mss 34531a.

Vignoles CB (1848) Letter number 1218 to Robert Stephenson dated 16 May 1848, in Letters of Charles Blacker Vignoles. Portsmouth Records Office (collection ref. 1072A).

Vignoles CB (1849a) Letter number 1225 to Colonel du Plat dated 11 May 1849, in Letters of Charles Blacker Vignoles. Portsmouth Records Office (collection ref. 1072A).

Vignoles CB (1849b) Journal of Charles Blacker Vignoles Volume IVb (1849-1850). British Library Additional Manuscripts collection ref. Add Mss 34531b.

Vignoles C (1854) Suspension Bridge over the River Dnieper near Kiev in Russia 1848-1853. Brochure to accompany model in Crystal Palace Permanent Exhibition.

Vignoles C (1857) On the adaptation of suspension bridges to sustain the passage of railway trains. Report of the 27th Meeting of the British Association for the Advancement of Science, Dublin, August and Sept 1857, John Murray, 1858. pp. 154-158.

Vignoles J (2006a) The design and construction of the Kiev Suspension Bridge - 1846 to 1853. Proceedings of the First International Conference on Advances in Bridge Engineering. Brunel University, June 2006. Vol. 1, pp. 72-85.

Vignoles KH (1982) Charles Blacker Vignoles: Romantic Engineer. Cambridge University Press, Cambridge.

Vignoles MJP (2006b) Vignoles, Kiev Suspension Bridge 18461853. Proceedings of the Second International Congress on Construction History. Vol. 3, pp. 3211-3232.

Vignoles OJ (1889) Life of C.B. Vignoles, FRS, Soldier and Civil Engineer. Longmans, Green and Co., London.

\section{WHAT DO YOU THINK?}

To discuss this paper, please email up to 500 words to the editor at journals@ice.org.uk. Your contribution will be forwarded to the author(s) for a reply and, if considered appropriate by the editorial panel, will be published as discussion in a future issue of the journal.

Proceedings journals rely entirely on contributions sent in by civil engineering professionals, academics and students. Papers should be 2000-5000 words long (briefing papers should be 1000-2000 words long), with adequate illustrations and references. You can submit your paper online via www.icevirtuallibrary.com/content/journals, where you will also find detailed author guidelines. 